TESTS OF CLAY PRODUCTS

BY

A. MARSTON. 



\section{TESTS OF CLAY PRODUCTS}

BY A. MARSTON.

\section{CONTENTS.}

Chapter VIII.

Tests of dry press building brick commonly used in Iowa ............ 558

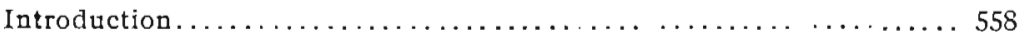

Key to kinds of brick.................................. 559

Compression tests . . . . . . . . . . . . . . . . . . . . 562

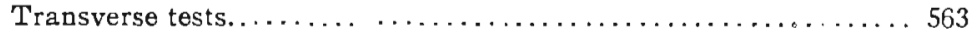

Absorption tests. . . . . . . . . . . . . . . . . . . . . 564

Freezing and thawiog tests . . . . . . . . . . . . . . . 565

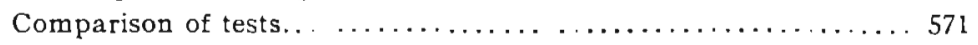

Strmmary of tests $\ldots \ldots \ldots \ldots \ldots \ldots \ldots \ldots \ldots \ldots \ldots \ldots \ldots \ldots \ldots$

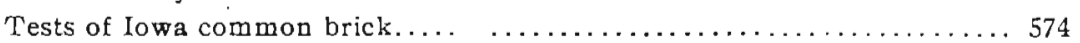

Introduction $\ldots \ldots \ldots \ldots \ldots \ldots \ldots \ldots \ldots \ldots \ldots \ldots \ldots \ldots \ldots \ldots$

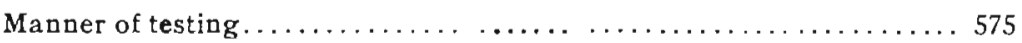

Brick tested............................... 576

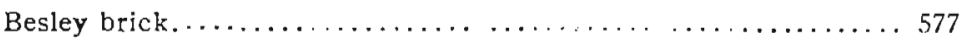

Webster City brick ......................... 577

Dale brick (Des Moines). ......................... 578

Grand Junction brick. . . . . . . . . . . . . . . . . . 578

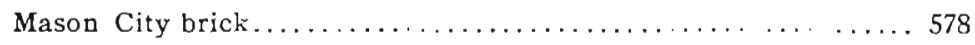

Ames and Kelly brick. . . . . . . . . . . . . . . . . . . . . . 579

Structure of trick tested . . . . . . . . . . . . . . . . . . . . . . . 580

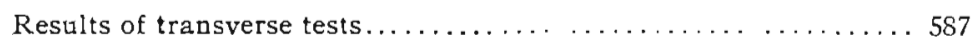

Results of absorption tests. . . . . . . . . . . . . . . . . . 589

Results of freezing tests . . . . . . . . . . . . . . . . . . . . 590

Comparison of tests ......................... 592

Table showing comparative results of brick tests . . . . . . . . . . . . 595

Rating formula . . . . . . . . . . . . . . . . . . . . . . 595 
Tests of strength of hollow building blocks ................. 593

Advantages of hollow blocks ........................ 599

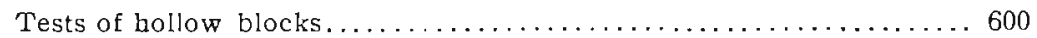

Tests of lowa paving brick . . . . . . . . . . . . . . . . . . 601

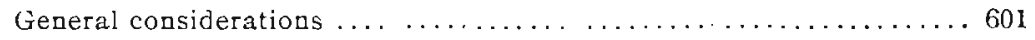

Advantages of brick paving . . . . . . . . . . . . . . . . . . 602

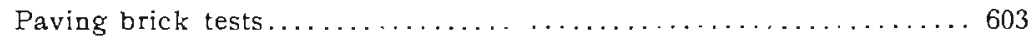

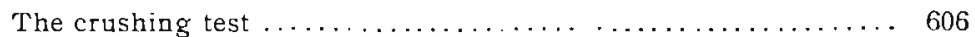

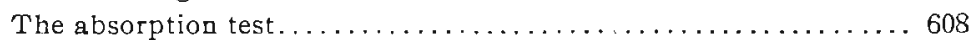

The transverse test . . . . . . . . . . . . . . . . . . . . . . 609

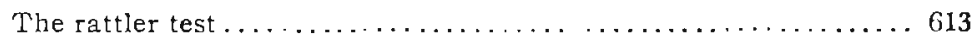

Specifications for standard method of conducting rattler tests 617

Table showing numerical values of rattler tests..........620

\section{CHAPTER VIII.}

Tests of Dry Press Building Brick Commonly Used in Iowa.

\section{INTRODUCMION .}

The series of tests described in this pajer was undertaklen with two aims in view. First, to deternine the relative qualities of the dry press building brick commonly in use in this state, especially with a view to defrmine whether or not the lome made brick were equal to thcse imported from adjoining. states; scound, to detomine in the course of the tests varjous points of scientific intrest in connection with the proprer methods of testing dry press building brick.

As regards the first of the above objonts it may be said that in the diagrams accompanying this pajer the relative rank of the diffrent kinds of brick may be readily suen. On these diagrams the different kinds of brick are indicated by letters for the sake of simpliciti. The key to the kinds is given in the following table: 
KEY TO KINDS OF BRICK.

\begin{tabular}{|c|c|c|c|}
\hline 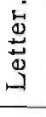 & KIND. & 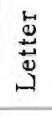 & KIND. \\
\hline $\begin{array}{l}A \\
B \\
C \\
D \\
E \\
F \\
G \\
G \\
H \\
I \\
J \\
K \\
\mathrm{~L} \\
\mathrm{M} \\
\mathrm{N} \\
\mathrm{O} \\
\mathrm{P}\end{array}$ & $\begin{array}{l}\text { Van Meter Red. } \\
\text { Van Meter Buff. } \\
\text { La Salle Buff. } \\
\text { Corey "a" Red. } \\
\text { Omaha } 10 \text { Red. } \\
\text { Dale Goodwin Buff "P". } \\
\text { St. Louis } 100 \text { Red Granite. } \\
\text { St. Louis } 500 \text { Mottled Gray. } \\
\text { La Salle I Red. } \\
\text { Corey } 7 \text { and } 9 \text { Buff. } \\
\text { Omaha } 555 \text { Buff. } \\
\text { Dale Goodwin Buff "B", } \\
\text { Gethmann No. } 10 \text { Red. } \\
\text { Gladbrook No. 1 Red. } \\
\text { Gethmann No. } 6 \text { Red. } \\
\text { Gladbrook No. } 3 \text { Red. }\end{array}$ & $\begin{array}{l}a \\
b \\
c \\
d \\
e \\
f \\
g \\
h \\
i \\
j \\
k \\
1 \\
m \\
n \\
o \\
p\end{array}$ & $\begin{array}{l}\text { Van Meter "d" Red. } \\
\text { La Salle No. } 2 \text { Buff. } \\
\text { La Salle No. 1. Mottled. } \\
\text { St. Louis } 7 \text { Red. } \\
\text { Corey } 20 \text { red. } \\
\text { Corey " } \\
\text { Corey } 16 \text { Red. } \\
\text { St. Louis } 500 \text { Steel Gray. } \\
\text { La Salle No. } 2 \text { Mottled. } \\
\text { St. Louis } 509 \text { Red Granite. } \\
\text { Omaha } 575 \text { Gray. } \\
\text { Omaha } 550 \text { Light Mottled. } \\
\text { St. Louis } 511 \text { Light Buff. } \\
\text { Omaha } 550 \text { Dark Mottled. } \\
\text { Omaha } 5 \text { Red. } \\
\text { Gladbrook No. } 6 \text { Red. }\end{array}$ \\
\hline
\end{tabular}

The capital letters refer to those kinds in which cubes were frozen and thawed 40 times, while the small letters refer to those frozen and thawed 20 times.

In figure 89 the bricks are ranked in the order of their transverse strength. While the rank would vary with the different tests yet it will be sem that brick A, the Tan Mater Red, ranked highest in all of the tests. This spealks well for Towa brick. Brick B, the Van Metri Butf, ranks next. This brick makes a beantiful material for building purprises. It lias been: used for the construction of the Chimes Tower of the Iowa State College at Amos, Iowra, and in this structure lias stood the tost of several years exposure to the elements. The tower remains as beautiful as it was when first erected and stands as a monument to the gnod quality of Iowa pressed brick.

Bricks D, e and g, Corey Red minufactured at Lehigh, Iowa, and bricks of and $f$, the Corey Buff mamufactured at the same place, are also most excellent brick manufactured in Iowa. Together with the Van Meter Buff the Corey Buff brick have heen used for the interior finish of the walls of the new Engineering 
Hall at Ames, which by many competent persous, luas been pronounced the finest building of its kind in the country. The use of buff, diy pressed brick for the interior" finish of churches and other public buildings is becoming deservedly popular. It makes a fuish which, unlike plaster, is permanent as wall as pileasing. If the walls should bcome stained with dirt they can be cleaned without the necessity of putting on a fresh coat of plaster, kalsomine or paint.

Bricks $F$ and L, Dale Goodwin Buff, manufactured at Grand Juncticn, and bricks $\mathrm{M}, \mathrm{N}, \mathrm{O}, \mathrm{P}$ and $\mathrm{p}$, all red pressed briok manufactured at Gladbrook, Iowa, by the Gladbrook Pressed Brick Company and by Gethmann. Brothers, are also excellent dry pressed brick.

This series of tests has thoroughly demonstrated that in quality Iowa dry pressed brick can compete with any manufactured in the country. Where the Iowa plants are lacking at present is, first, in their facilities for malking brick in sufficient quantities so that architects and contractors can rely upon their being obtained without undue delay; and second, in their facilities for supplying diffcrent architectural grades of brick. Both of these deficicncies are of such nature as to be readily supplied by Iowa. manufacturers. The question of quantity is one simply of a plant large enough for carrying on the work. The writer has had unfortunate experiences in getting; Iowa dry pressed brick in quantitios sufficient to enable the rapid carrying on of work in which he has specified their use. The quality of the brick is such that if well advertised and exploited there should be no trouble in dispesing: of the products of large plants.

The question of different architectural grades of brick is one for exprrimentation with different qualities of material and with the substances commonly used to roduce the different colors and surfaces needed for architectural appearances. It is now possib]e to have samples of clay sent to the Ceramic Tuab- 
oratory at Ames, and there tested to deternine what can be attained along these lines. There is no doubt that any enterprising manufacturer of good dry press brick could develop a suffcient number of kinds of brick to meet all necessities.

Incidentally, by the way, the query may be propounded, why do not the manufacturers of dry pressed brick in. Iowa turn out to the meetings of the Brick and Tile Association, and display a public interest in the advannement of this industry? In the procuring of the specimens for these tests more trouble was experienced with one of the Iowa manufacturers than with all of the companies outside of the state. It is difficult to understand why this should be so when the tests were carried on without expense to the manufacturers and were planned mainly for their benefit.

It is to the second of the purposes for which these experiments were planned that this discussion will be mainly confined. To indicate what degree of reliability may be given to the conclusions reached, the number of tests may be stated; in all about 800 transverse tests were maide; 100 crushing tests; 128 specific gravity determinations; 128 freezing and thawing: tests. In all some 32 grades of dry press building brick from eight different companies were thoroughly tested, and severai grades were partially tested. In testing each grade of brick twenty or more transverse lests were first made. From the ends of these broken brick cubes were then prepared for the crushing, absorption, specific gravity, and freezing and thawing tests.

The transverse tests were carried out in the manner adopted as standard by the Department of Civil Engineering of the Iowa State College for making surb tests. Kmife edges six inches apart, rounded both ways, were used to support the brick which were placed on edge in the machine. An adjustable knife edge was used at the top to apply the loadi mid-way be- 
tween the supports. Steel bearing blocks were used between all knife edges and the brick to keep the knife edges from cutting into the brick and causing failure from local injury.

The crushing tests were partially made on two-inch cubes with two smooth surfaces at top and bottom, the bearing surfaces of the testing: machine being steel plates. Other tests from the same brick were made upon specimens of larger size, each about one-third of a brick placed flatwise in the machine, and bedded above and below with plaster of Paris. The absorption, specific gravity, and thawing; and freezing tests were all made upon four different kinds of cubes for each grade tested. For each grade two-inch and one-inch cubes ground truly to shape and size were tested, andi also two-inch and oneinch cubes simply chippedi ont approximately to shape and size, but with surfaces left rough.

Compression Tests. - In fig. 82, the results of the compression tests are shown, and it will be noted that the tests of two-inch cubes with steel bearing plates showed considerable higher re-

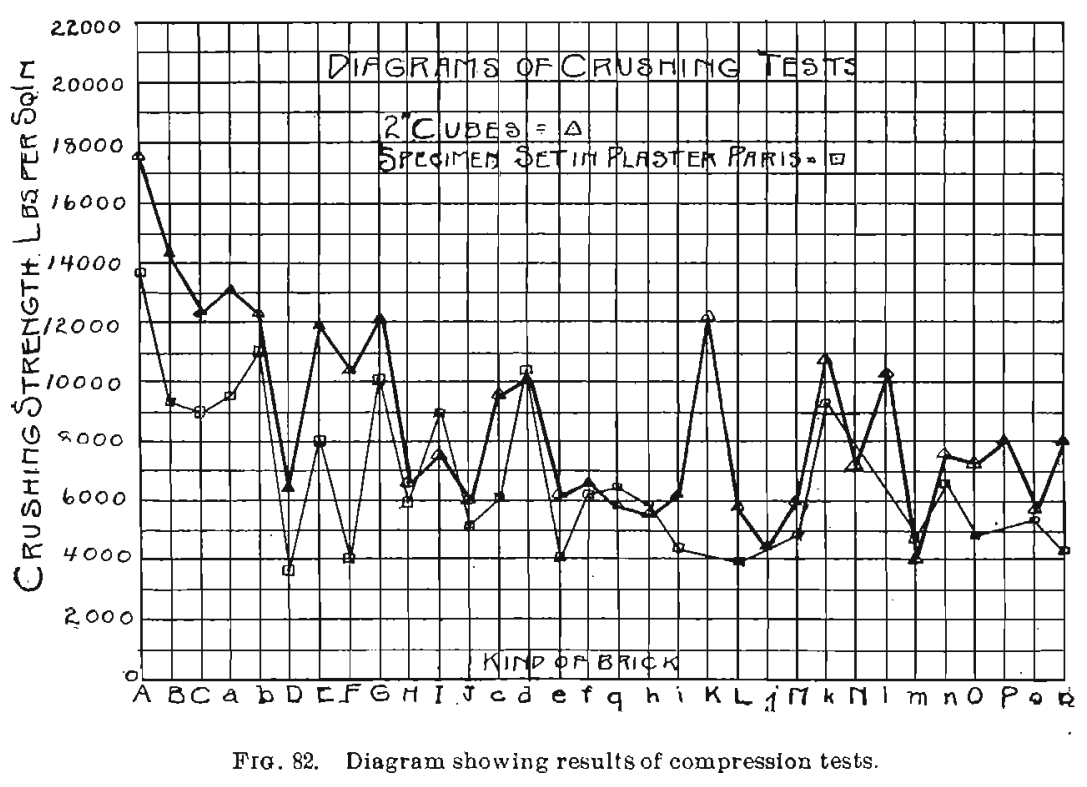


sults than the tests of specimens set in plaster of Paris. For standard tests: the writer is of the opinion that the specimens should be ground to two-inch cubes andl steel bearing surfaces used.

Trawserse Tests. - In fig. 83 four typical transverse tests were platted in detail. The transverse tests for the other grades would show similar results. The point brought out specially in these diagrams is the great lack of uniformity of the different individual specimens of the brick tested. Practical brickmakers are thoroughly aware that in each kiln of brick they make, all qualities of brick are found, from those too soft to use for any purpose, to: those which are the best that they can turn out, and still further to those that are so over-burned as to be of no value for building purposes. Engineers and architects, however, in their specifications and in their modes of

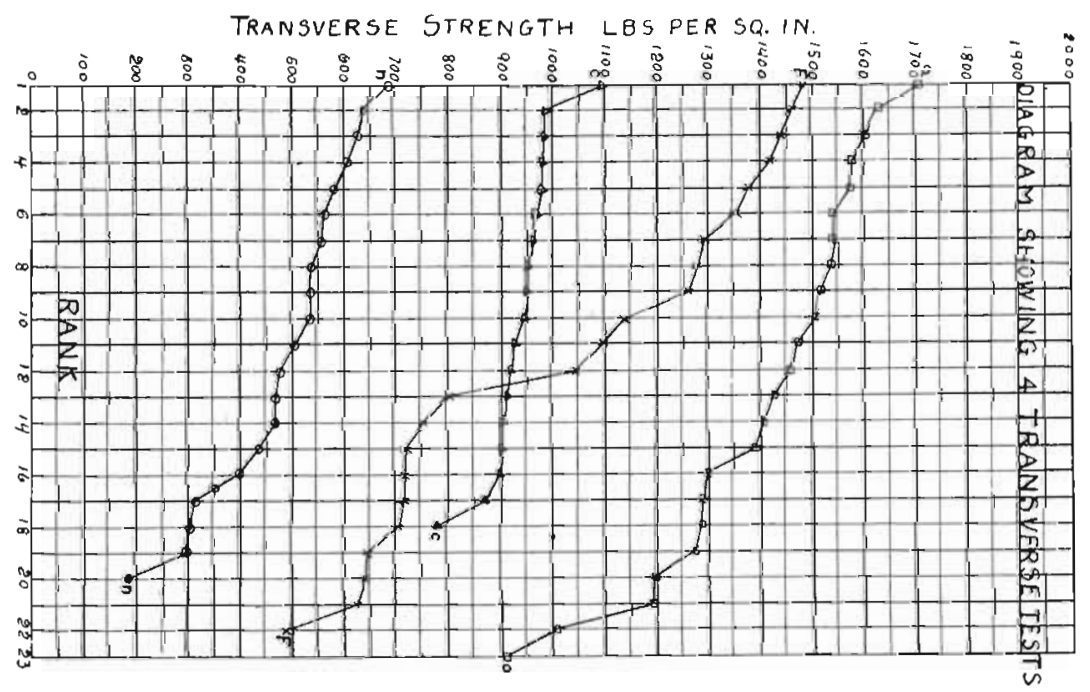

F1a. 83. Diagram showing results of transverse tests.

testing, seem to have overlooked, or not to have understood, this fact. Where the lack of uniformity is so great as is indicated by these transverse tests, it is evidently useless to try to rank 
brick by tests of only a few from each grade, yet that is what is commonly attempted. It is often urged against transverse tests that they fail to give uniform results, but as the outcome of having personally seen to the carrying out of thousands of transverse tests the writer wishles emphatically to express his cpinion that the transverse tests truly indicate the facts regarding the structure of the brick. They are to be commended, instead of condemned, because they bring. out these facts. The writer has carried on such tests by the hundred, making comparison of the structure of each brick with the results of the transver'se tests, and he is firmly convinced of the value of the transvierse tests as indicating the quality of the brick. One of the most valuable characteristics of transverse tests is the facility with which they are made. On account of this facility a large number can be carried out for each grade of brick tested, and the average will give results correspondingly more reliable than those of a small number of brick.

The other tests also gave widely varying: results when made upon different specimens of the same grade of brick. This is to be carrefully borne in mind whenever an attempt is made to compare the ranking of different grades of brick by the results of the different tests, and it explains the most of the discrepancies which are usually notied.

Absorption Tests.-In figs. 84 and 85, the final results of the absorption tests for the different grades of brick are shown. In carrying out the absorption tests the specimens were first dried in an oven until they showed no further loss of weight from evaporation, and were then completely immersed in water and weighed at intervals. All the speeimens showed a rapid absorption of water within the first three or four hours, and after the first twenty-four hours they showed a small, but still quite appreciable, increase in absorption. The specimens were left immersed about ten days, and at the end of the experiments 


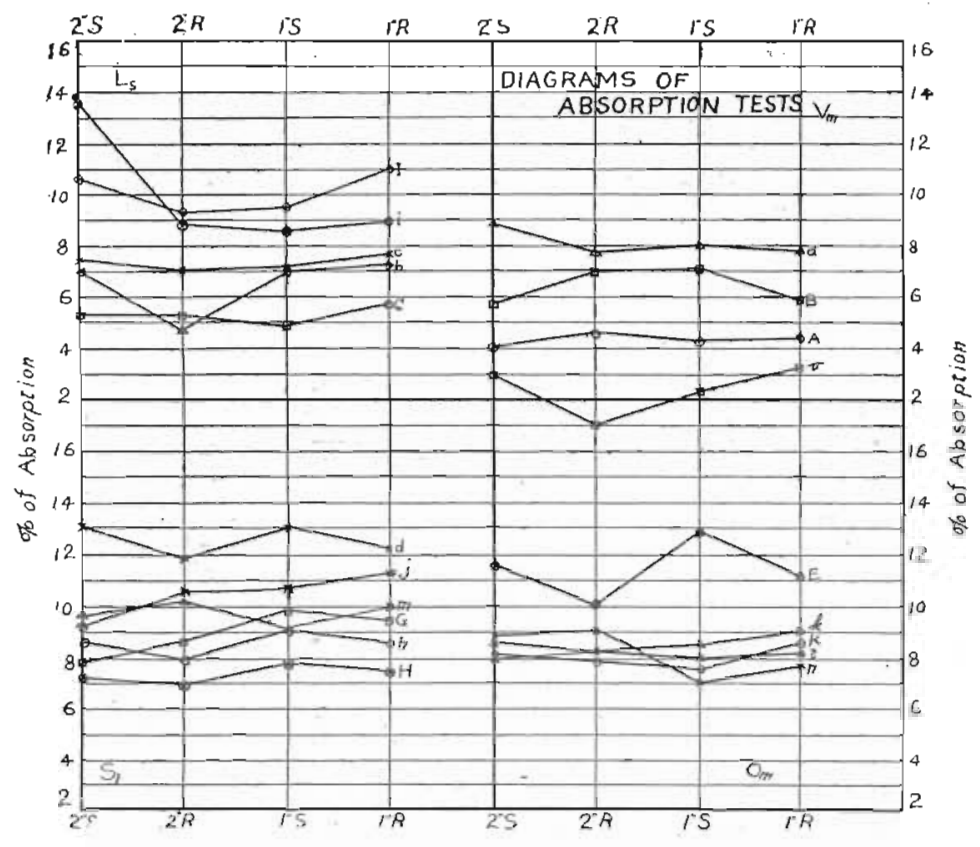

Fig. 84. Diagram showing results of absorption tests.

they were still absorbing water, so that the results given cannot be taken as the final per cents which they would take up. In figs. 84 and 85 , the results of the different eubes are indicated by the figures and letters. 2" S indicates the two-inch smooth cube; $2^{\prime \prime} \mathrm{R}$ indicates the two-inch rough cube, and the one-inch smooth and the one-inch rough cubes are indicated in similar ways. A careful study of the diagrams will show that there is no very great difference in the results with the different specimens. On the whole, however, the smaller cubes give slightly greater per cents than the larger cubes.

Freesing and Thawing Tests.-In figs. 86 and 87, the results of the freezing and thawing tests are indicated in a similar. manner. These freezing and thawing tosts were made upon the specimens saturated for the ahsorption tests. These were put into a freezing box, in which a temperature of from zero to six 


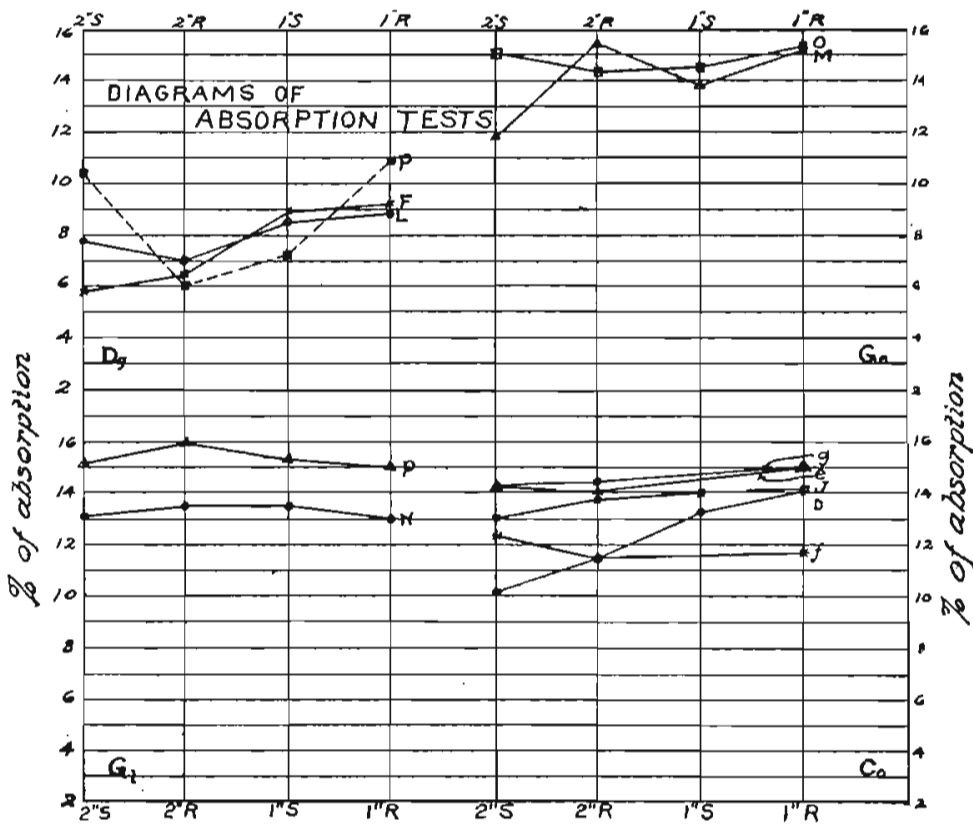

FIG. 85. Diagram showlng per cent of absorption of brick tested.

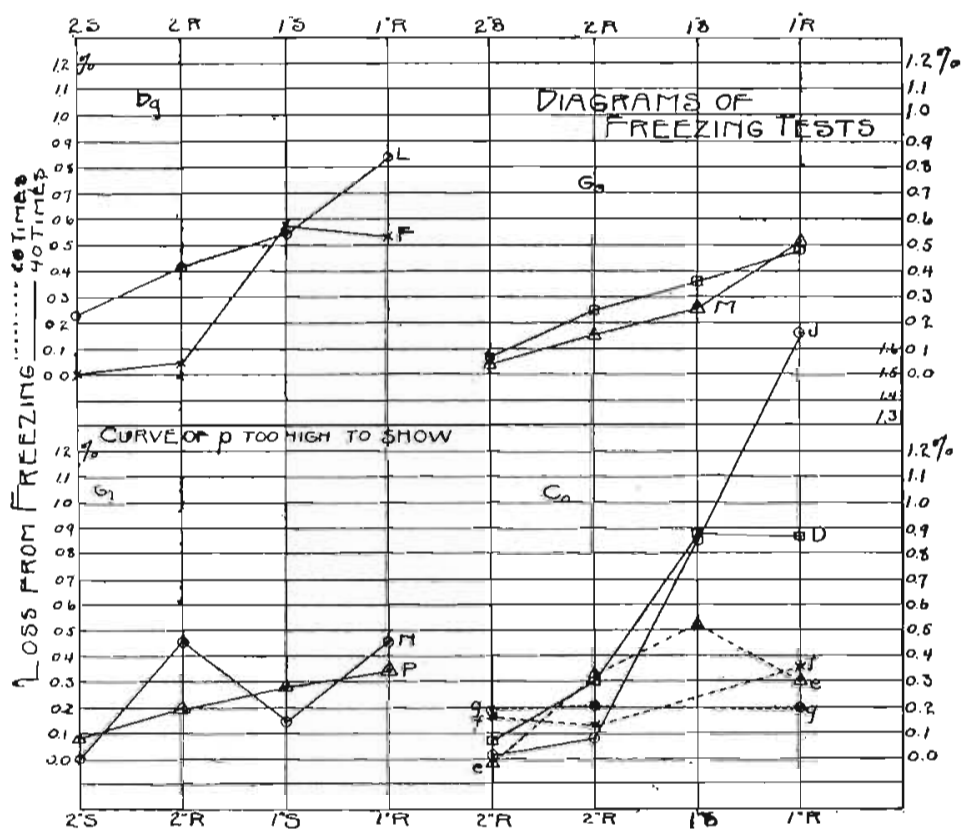

FTa. 86. Diagram showing results of freezing tests. 
degrees above nero $\mathrm{F}$. was maintained by a mixture of salt and ice. During the first twenty freezings and thawings the specimens were first frozen forty-eight hours, and then thawed by immersing in water for twenty-four hours. After the first twenty tests, the time of freezing was reduced to twenty-four hours, as the temperature records indicated that the cubes were completely frozen in that time. The writer advocates the twenty-four hour period as standard for such tests. The results of the tests show clearly that the rough cubes give greater losses than. the smooth cubes, and that the small subes give

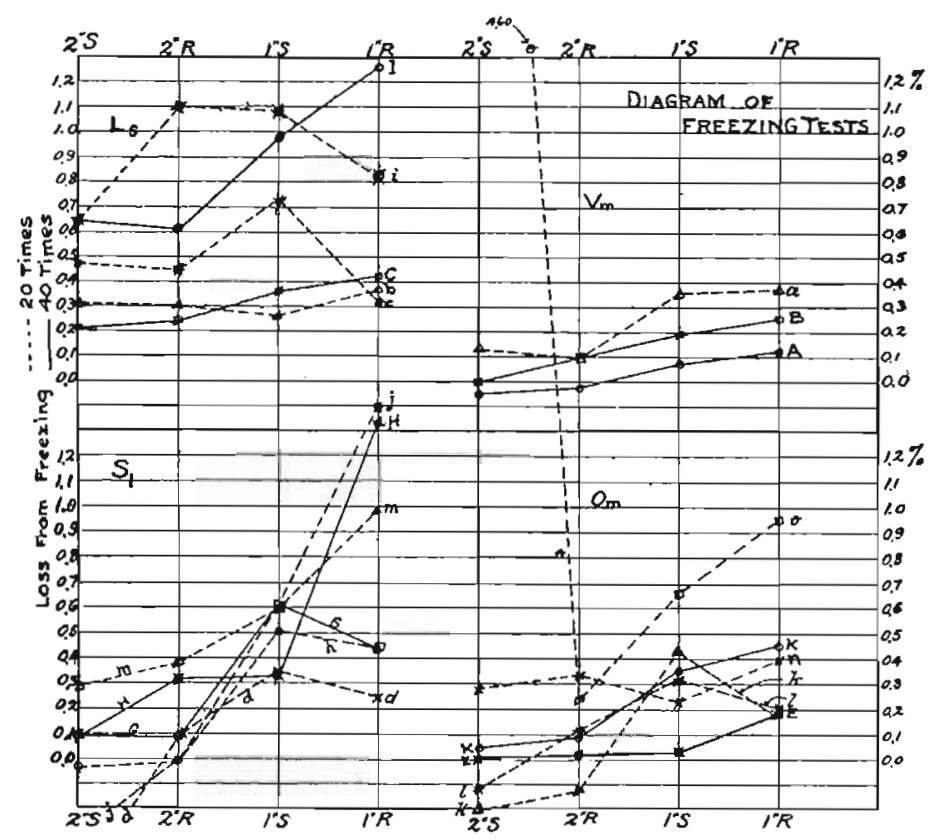

FIG. 87. Diagram showing enmparative loss on a varying numbe: of freezings.

greater losses than the large cubes. The writer advocates as standard for freezing and thawing tests one-inch smooth cubes. The rough cubes would give higher losses, but the smooth surface of the one-inch cubes enables the disintegration to be seen more clearly by the naked eye or under the microscope than is possible with the rough cubes. 


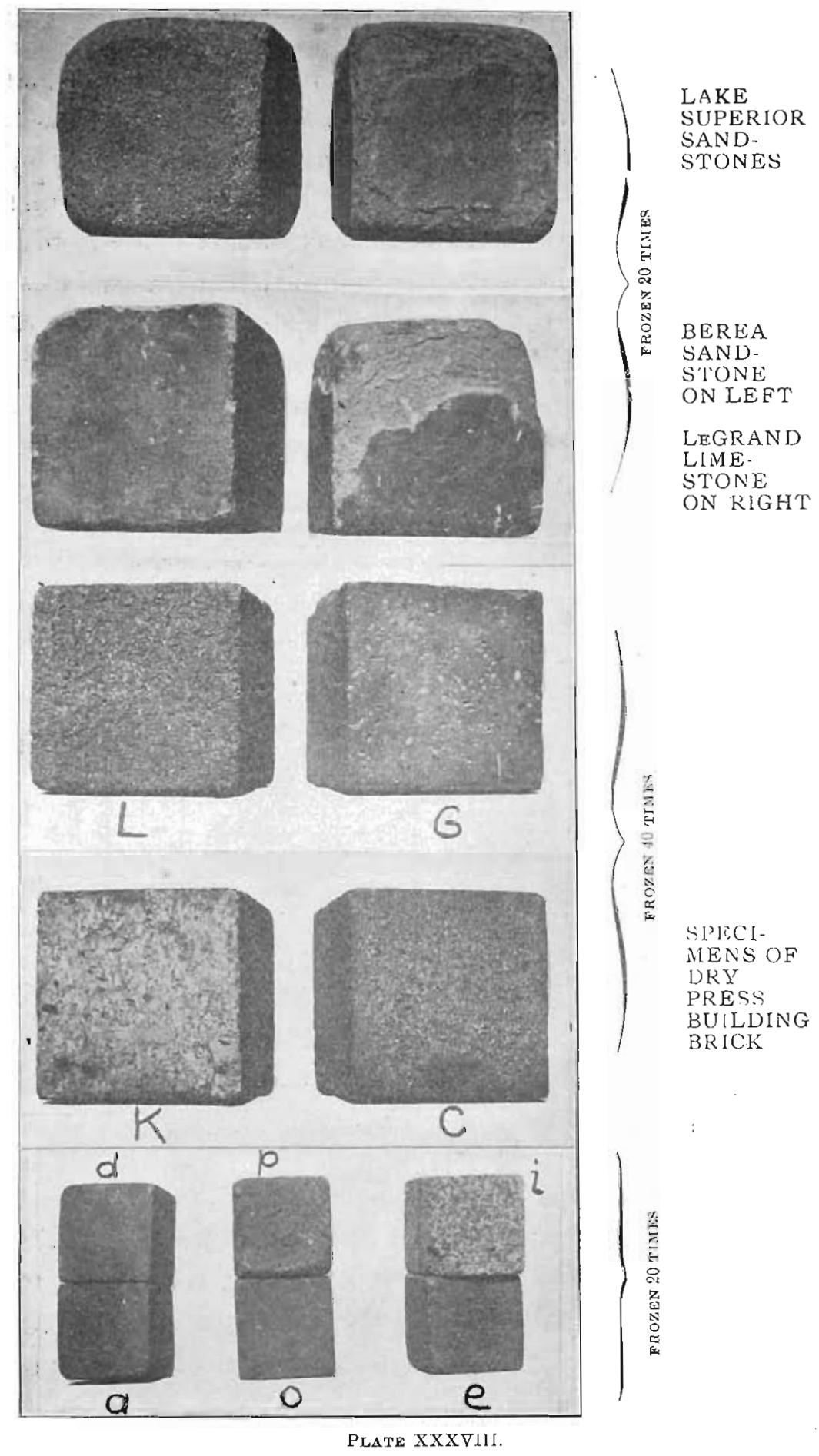


In plate XXXVIII some photographs of the smooth cubes subjected to the freezing and thawing tests are given. The four cubes at the top of the figure represent tests of some commonly used building stones, and are shown here for comparative purposes. These were two-inch cubes and were frozen and thawed twenty times. It will be seen that the effects were very marked. In other tests of commonly used building stones some cubles show very little effect, while in one case a oube of , Toliet stone was entirely destroyed. Buff Bedford stone showed about the same effect as the cube of Berea sandstone. Blue Bedford stone was apparently unaffected, as were also some cubes of Anamosa stone and the best grades of Lefrand stone. The four two-inch cubes shown immediately below the four cubes of building stone represent freezing and thawing tests made forty times upon specimens of the dry press brick. It will be seen that double the number of exposures produced much less effect than in the tests of the building stone, and, in general, it may be said that the tests on the best grades of dry press brick compare very favorably indeed with the tests of our best building stones. In the lower part of plate XXXVIII are shown the results of twenty freezing and thawing tests of six one-inch cubes of dry press brick. The cubes shown in plate XXXVIII may be taken as representative of the results of the tests of the dry press brick.

In the climate of Iowa the freezing and thawing test is the only direct one which can be applied to building brick, to duplicate the conditicas nuder which they fail in actual use. \& close observer will lcadily find many instances in any Iowa town in which the ordinary building brick show serious evidences of disintegration from freezing and thawing. These effects are especially to be looked fer near the ground and directly under the coping. The only objection to the freezing and thawing test for building brick is the great expense and large amount of time required to carry it out. To freeze and thaw brick forty times in the manner followed in these tests would require eighty 
days of continuous test, and unless a large number could be carried through at a time the expense per test would be great.

Since these tests were completed, however, as a result of further experimenting it has been found prossible to redluce the time required by one-half, by freezing one-inch cubes twenty hours each day and thawing them four hours in hot water. This method is now adopted as standard in the writer's laboratory. The use of one-inch cubes enables a very large number of specimens to be treated at one time and the result is to: greatly cheapen and simplify the freezing and thawing test.

The transverse test of brick is the one most readily and cheaply made, and as it detects all hidden flaws and enables a close study to be madie of the internal structure of the brick, it is of great value, although to be considered simply as an indirect test. Close observation in carrying out such tests has shown the writer that the finer grained, more uniform and dense the structurle of the brick, the ligher will be the transverse strength; and also, the better bulned the brick is the greater will be its transverse strength. We may heace consider it to be a fair measure of the quality of the brick for ordinary purposes, and it is of especial value because it can readily be made on a large number of specimens. To indicate how well the results of transverse tests conform to the results of freezing and thawing tests, fig. 88 is given. In this figure the brick tested have been grouped in the order of their ramk, as shown by the transverse tests, and the results of the freezing and thawing tests are platted on the same diagram. It will be seen that there is a general agreement between the tests, although there are wide variations from the general rule. These variations are largely to be explained, the writier thinks, by the fact that the freezing and thawing tests were made on a very small number of brick from each grade, sometimes not more than two, while the 
transverse tests give the average in each case of more than twenty brick. The results of the freezing and thawing tests also are to be taken as comparative rather than absolute, because in the work of the testing: some brine came in contact with the brick, and it is certain that not quite all of the salt absorbed was gotten rid of before the weighings. This fact will explain some apparent discrepancies in figs. 86 and 87.

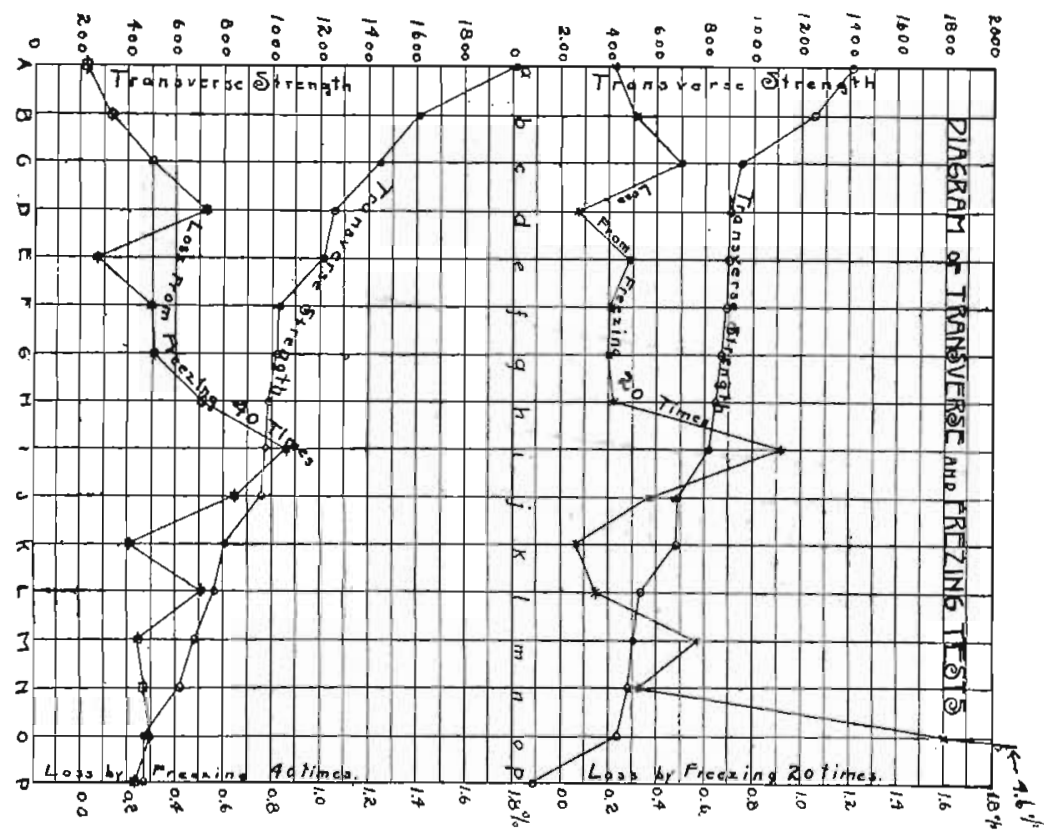

Fra. 89. Diagram showing results of transverse and freezing tests.

COMPARISON OF THE ABOVE TESTS.

To enable the comparison to be madio between the results of all the different tests made on these brick, fig. 89 has been constructed. In this figure also the brick are ranked according to the results of the transverse tests, as all the other tests were made on a comparatively small number of specimens. It will be seen that there is a general agreement between the results of the different tests, with many discrepancies, however. These discrepancies are largely to be explained from the great lack 
of uniformity which, as has already been shown; exists between different individual sjecimens of the same grade of brick, and from the fact that in all but the transvel"se tests only a small number of sperimens were tested. The general agrement of the different tests is most readily seen by comparing the best grade with the poorest. In this case the same grade ol brick

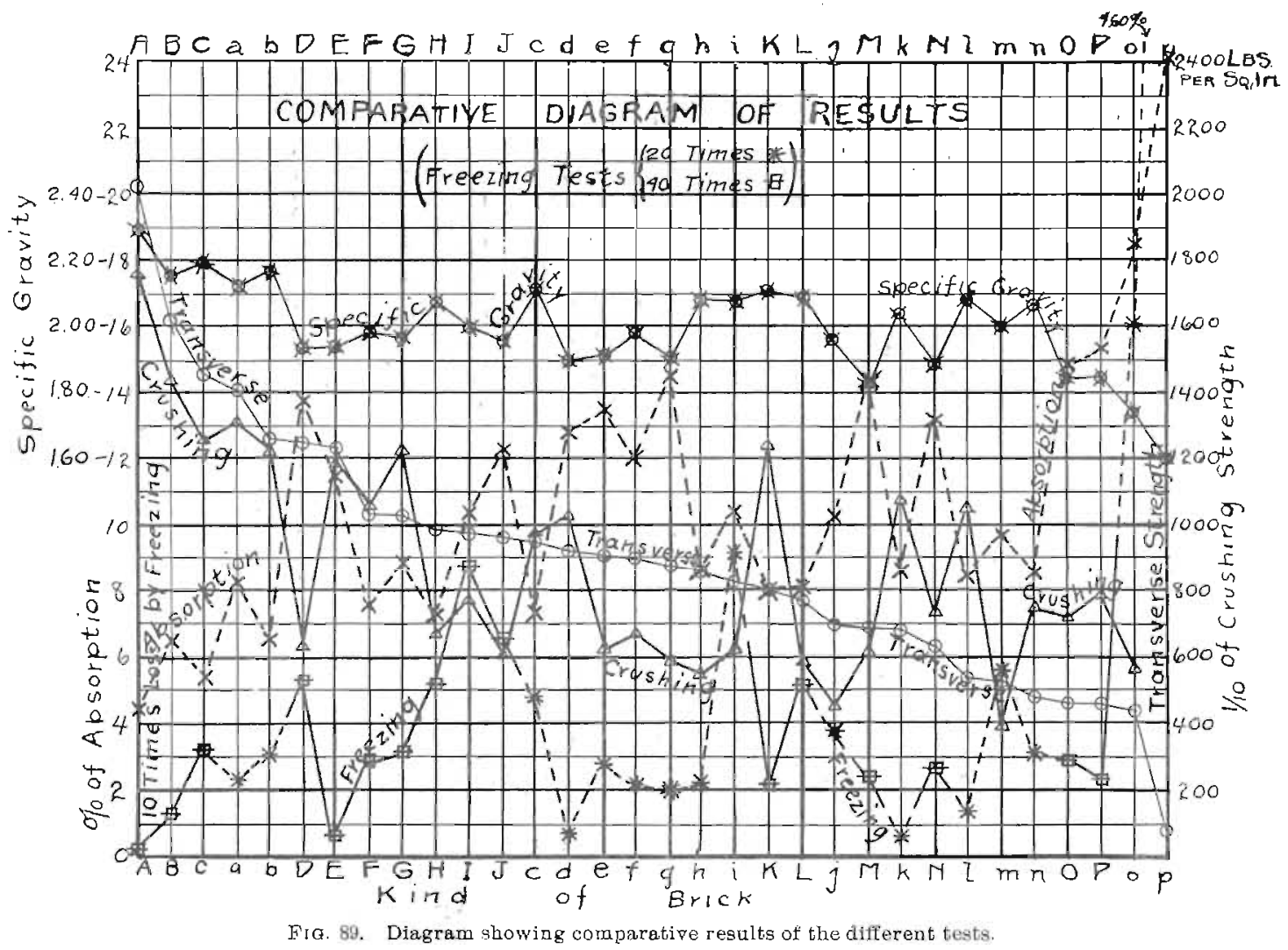

which gave the highest transverse strength had also the highest crushing strength, the lowest per cent of absorption, the smallest loss from freezing and thawing, and the highest specific gravity; while the bick which showed the lowest transverse strength was poorest in all the other tests which were made upon it. This poorest brick was one too soft to rank as 
anything but an ordinary building brick, and wass sent by special request made to the makers. It would probably be a better brick, however, than most of the ordinary sand brick used for building purposes in Iowa.

SUMMARY OF TESTS.

It would seem advisable to recapitulate the principal conclusions brought out by the discussion of this series of tests, as follows:

First. The best brick tested was an Iowa brick, and there appears to be no reasor why the very best quality of dry press brick should not be made in Iowa.

Second. There is a great lack of uniformity in different brick from the same grade and the same kiln, and a large number of tests should be made to secure reliable deductions as to the relative rank of different grades of brick. The writer may add in this connection that in his opinion the making and interpretation of such tests should be intrusted only to experts who are perfectly familiar with the actual processes of the manufacture of brick.

Third. Crushing tests should be made upon two-inch cubes, with steel bearing plates.

Fourth. The size and character of the surface of the specimen make little difference in the results of absorption tests within the range of one-inch to two-inch cubes. Ten days immersion does not give complete saturation.

Fifth. One-inch smooth cubes should be adopted as standard for absorption and for freezing and thawing tests. These cubes: should first be immersed in water and weighed, first at very short intervals, and then at longer intervals, until they are practically saturated. They should then be placed in a freezing box, in which the temperature should be 0 to $6^{\circ} \mathrm{F}$. constantly maintained. This temperature can readily be attained 
by the use of salt and ice. The oubes should be frozen twenty hour's each day and thawed four hours in hot water having a temperature of about $150^{\circ} \mathrm{F}$.

Sixth. The transverse test is one of the most valuable tests which can be made on brick. In carrying it out the briok should he placed on edge on knife ediges six inches apart, rounded both ways, as for standard tests of paring brick. The pressure should be applied by a knife edge adjustable or rounded both ways, the steel bearing: plates should be used between all knife edges and the surfaces of the brick. The brick should not be gromond or prepared in any way for the transverse test. Careful study should be made of the internal structure of each brick in comprarison with the results of the test upon it.

In conclusion the writer desires to say that the greater part of this series of tests was made by Messrs. George A. Smith, B. C. E., and F. I. Nichols, B. C. E., graduates of the Department of Civil Engineering of the Iowa State College, as thesis work. It is their earnest and painstaking work which has enabled the tests to be made.

\section{Tests of Iowa Common Brick.}

\section{INTRODUCTION}

The following tests of common brick were arried out by the civil engineering department of the Iowa State college during the year 1902. The tests were undertaken as thesis work by Messrs. J. F. McBirney and J. E. Stewart, two senior students, who did most of the testing and calculating, and platted many of the curves. The writer desires to call especial attention to their painstaking work, and to say that without such invaluable assistance from students, given without remuneration in money, the investigations of Iowa brick heretofore reported by him, as 
well as those now to be discussed, could not have been undertaken.

Previous tests of Iowa brick have been made of pavers and of dry press brick. The following tests are the first in which many data of the properties of common, brick in this state have been ascertained. The greater part of the brick: manufactured in the state are common brick and there is room for great improvement in the methods of manufacture. It should be understood by manufacturers and users of such brick that the testing of the product is one of the best means to bring about these improvements.

\section{MANNER OF TESTING.}

The brick were tested in four ways: viz., for transverse strength, erushing strength, percentage of absorption; and resistance to freezing and thawing. The transverse tests were made uyon brick placed flatwise, on knife edges six inches apart, the knife edges being rounded both ways. Steel bearing blocks $3-t^{\prime \prime} x$ $3-4 "$, a little less in length than the width of the brick, and with rounded edges, were placed between the kmife edges and the brick. The crushing tests were made between adjustable steel plates, on two-inch cubes, ground out by an emery wheel. The absorption tests were made on one-inch cubes, immersed in water and weighed at intervals up to two or more weeks, but the brick are compared on the basis of forty-eight hours immersion. On the completion of the absorption tests the freezing tests were made by placing the saturated one-inch cubes in a freezing box where they were subjected to a minimum temperature of about one or two degrees above zero Fahrenheit, for twenty-four hours; then thawed in water twenty-four hours, then re-frozen twenty-four hours, etc., until the cubes were demolished. 
Twenty-five bricks of each kind were broken in the transverse test. From the broken iends of ten of these the cubes were prepared for the other tests. Another set of transverse tests with the brick placed on edge was also madie. In all six hundred and twenty-six transverse tests and one hundred and thirty each of crushing, absorption and freezing tests were made.

BRICK RESTED.

The brick tested were the product of seven different Iowa brick plants: viz., L. C. Besley, Council Bluffs; The Webster City Bricki and Tile Company; The Dale Brick Company, Des Moines; the Goodwin Tile and Brick Company, of Grand Junction; the Mason City Brick and Tile Company, of Mason City;

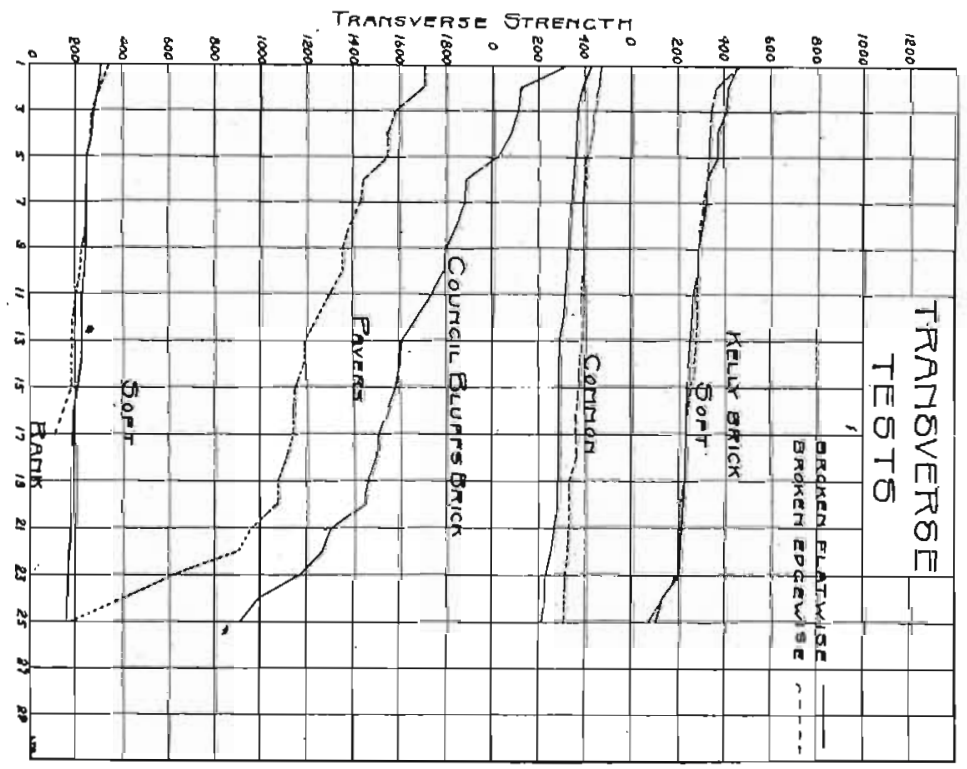

Fra. 90. Transverse tegts, Council Bluffs brick.

the Kelly Brick and Tile Company, and the yard formerly op erated by Mr. Cameron just west of the college. The following brief description of the clays and the processes of manufacture used in these different establishments has been prepared by Prof. S. W. Beyer. 
Besley Brich-- 1 ll brick in and about Council Bluffs are made from loess clays or modified loess in the form of wash from the adjoining: biluffs. Mechanical analyses show that fine sand and silt predominate with a lessur quantity of clay substance. Practically the entire mass will pass through a $100-$ mesh sieve. A small percentage of lime is usually present in a finely divided state and occasionally in the form of concretions and molluscan shells. Other deleterious elements are rarely present.

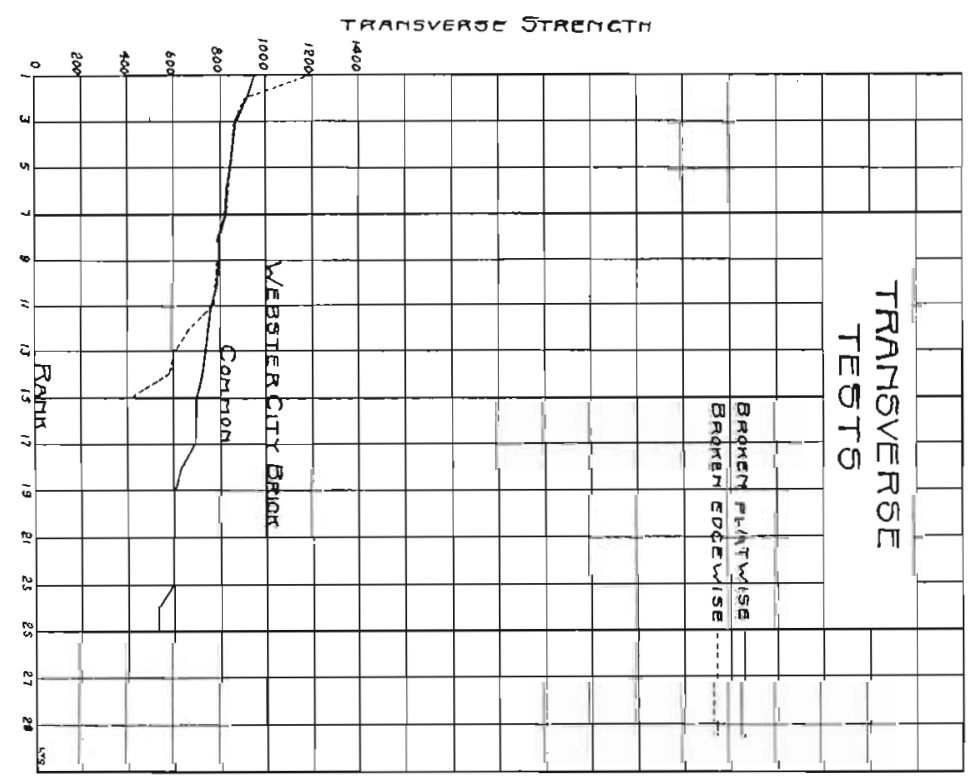

FIG. 91. Trausverse tests, Webster City brick.

Webster City Brick.-Averages about one part shale obtained from the Des Moines stage of the Coal Measures to two parts surface wash and alluvium. The shale is variable in color, fissile and fairly plastic. The surface material contains a high percentage of fine sand andi silt with but little clay substance, and some lime in a finely divided stats. 
Dale Brick (Des Moines).- The raw material is ordinary alluvium mixed with wash and loess. Sand and silt constitute the larger portion with a smaller balance of clay substance. No deletericus elements are prownt.

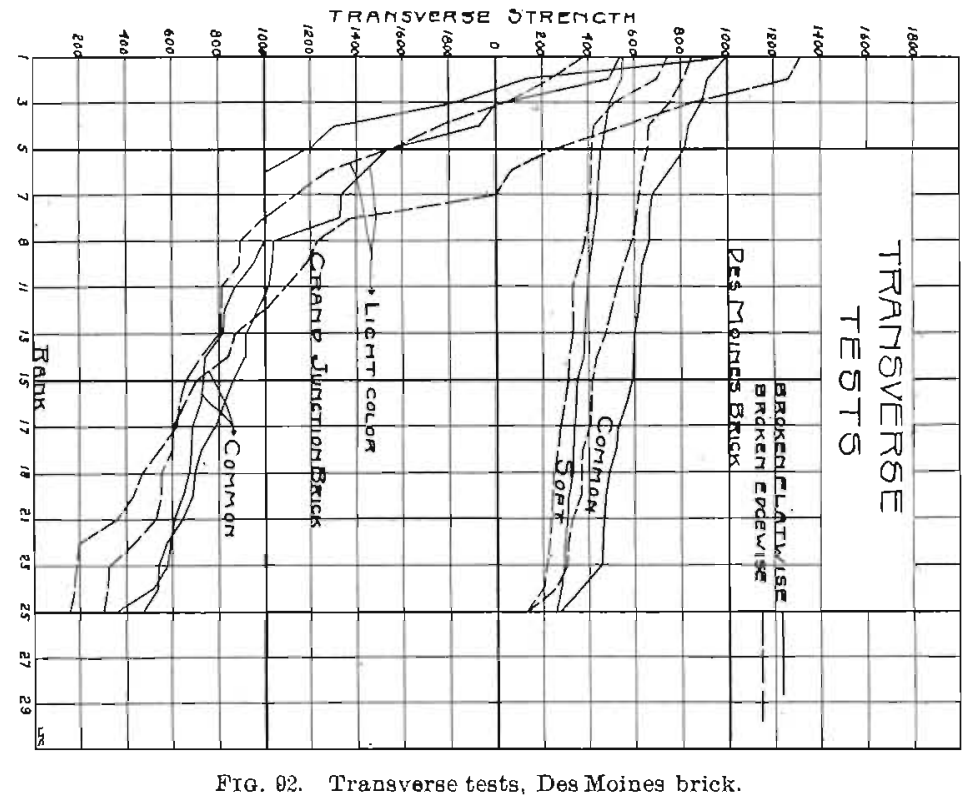

Grand Junction Brick.-The ram material consists of a mixture of shale and fire elay and belongs to the Des Moines stage of the coal Measures. The shale is slightly pyritic and moderately fissile and worlzs into a plastic mass. The fire clay is plastic and non-fissile and more or less leached of the fluxes. The green brick is a heterogeneous mixture of the two.

Masun City Brick. - The material used is a shale clay belonging to the Lime. Creek stage of the Devonian. The unaltered clay is blue-gray in color, exceedingly fine-grained, highly plastic, and but imperfectly jointed, and shightly fissile. The irregular joints often contain gypsum cleavage flakes and crystals. Iron pyrite grains irregularly distributed and with the gypsum foum the only grit which can be detected throughout the beds. 
The upper portion of the clay beds are somewhat iron-stained to varying shades of yellow and brown, the stains following the jointings down to a considerable deptl. Lime in a finely divided state is present throughout the deposit.

Ames and Kelly Brick.-The material is rractically the same and belongs to the loess. The beds used in each rase have been

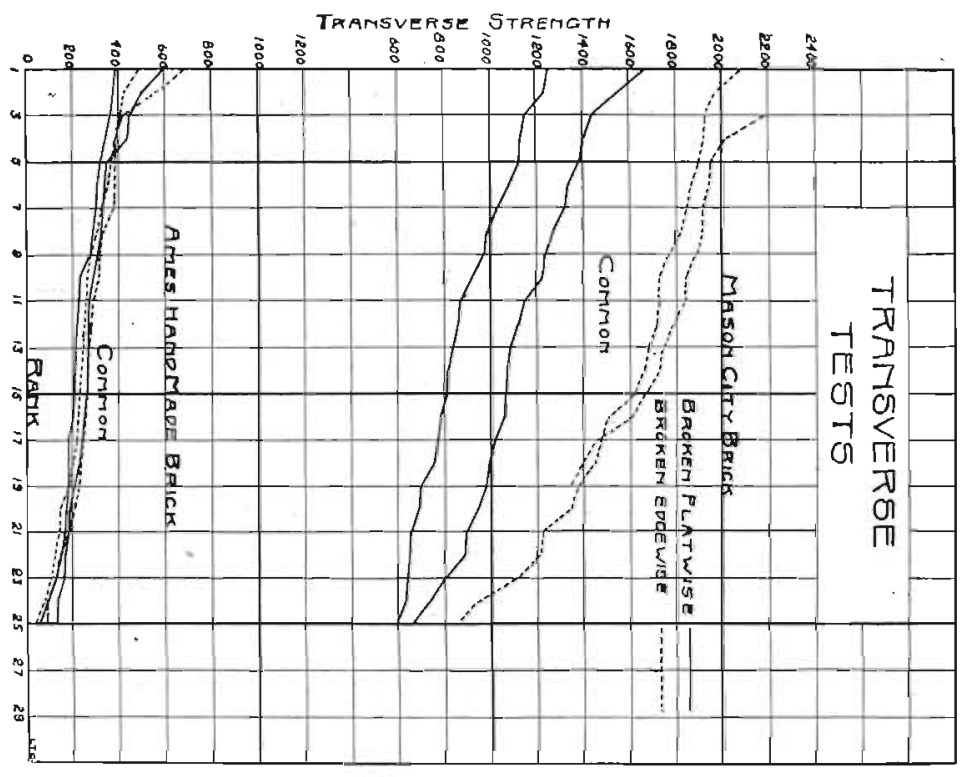

Frg. 98. Transverse tests, Mason City brick.

covered by the Wisconsin drift which necessitates consiclerable stripping. The loess elay at these places contains less fine sand and silt and more clay than does the Missouri river loess. It also contains more lime, both disseminated and in the for'm of concretions, and occasionally contains iron pyrite. Here, as is ustal with loess deposits, the beds run sandier belew and as in all loess clans the green ware is very tender and requires careful liandling. 


\section{STRUCTURE OF BRICK TESTED.}

Regarding the structure of the brick it may be said that the Council Bluffs brick were soft mud, machine made brick and were very fine-grained and homogeneous in texture, and free from laminations, the only noteworthy irregularity king the poor structure of the under side of the brick in the molds of the soft mud machine. Two grades were shipped by Mr. Besley for the tests, one grade consisting of very hard burned brick,

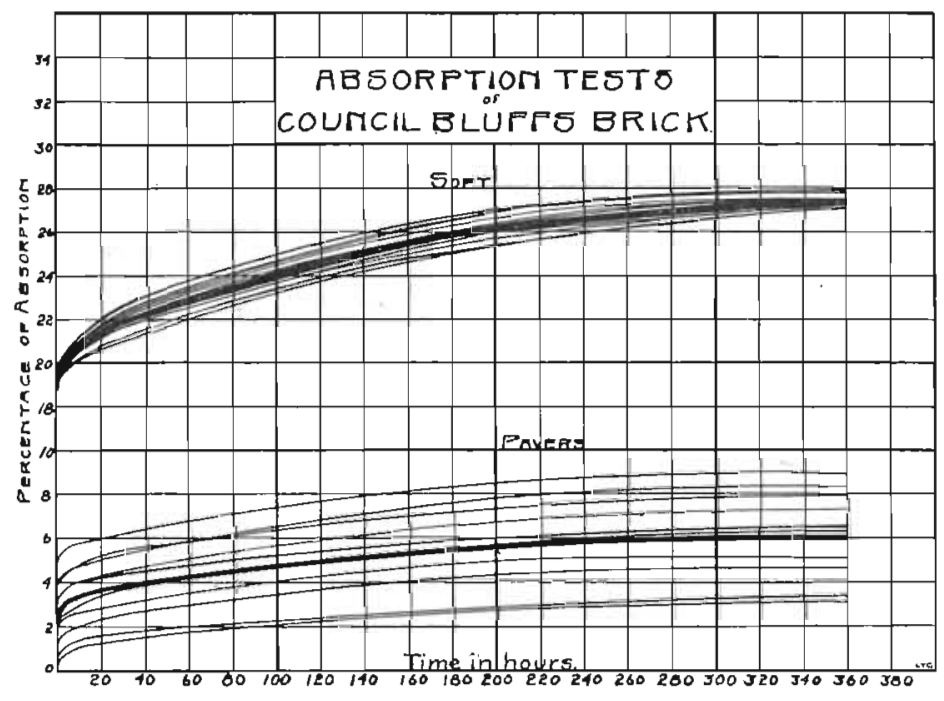

Irra. 94. Absorption tests, Council Bluffs brick.

gocd enough for parvers, while the other" grade was composed if soft, under burned brick.

Only one grade of Webstre City brick was tested and this concisted of hearvy and uniformily well burned, stiff mlud, side cut, brick. The interior structure show'ed a mixture of materials, which gave a rather locse appearing texture, but the mixture was quite uniform, the color indicated tholough buning, and the weight indicated that the porosity could not be great and the brick were hard. 


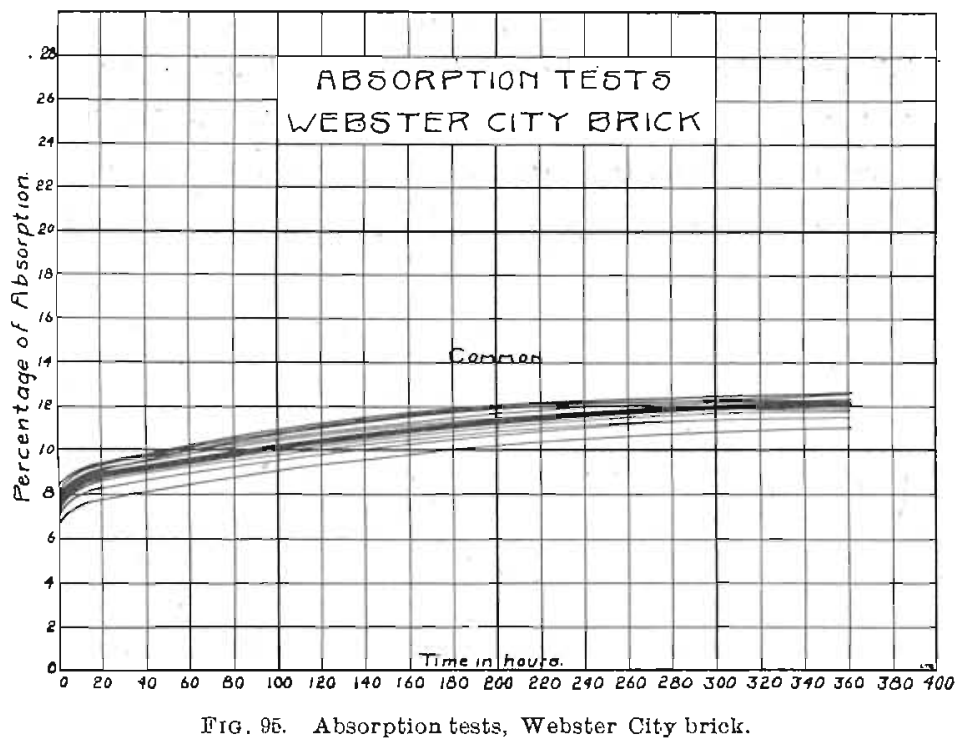

The Dale brick from Des Moines were selected as fairly reprenontative of several cars shipped for the backing of the walls of the new: Engineering Hall of the Iowa State College. All wiere stiff mud, side cut brick. Those hereinafter designated "com-

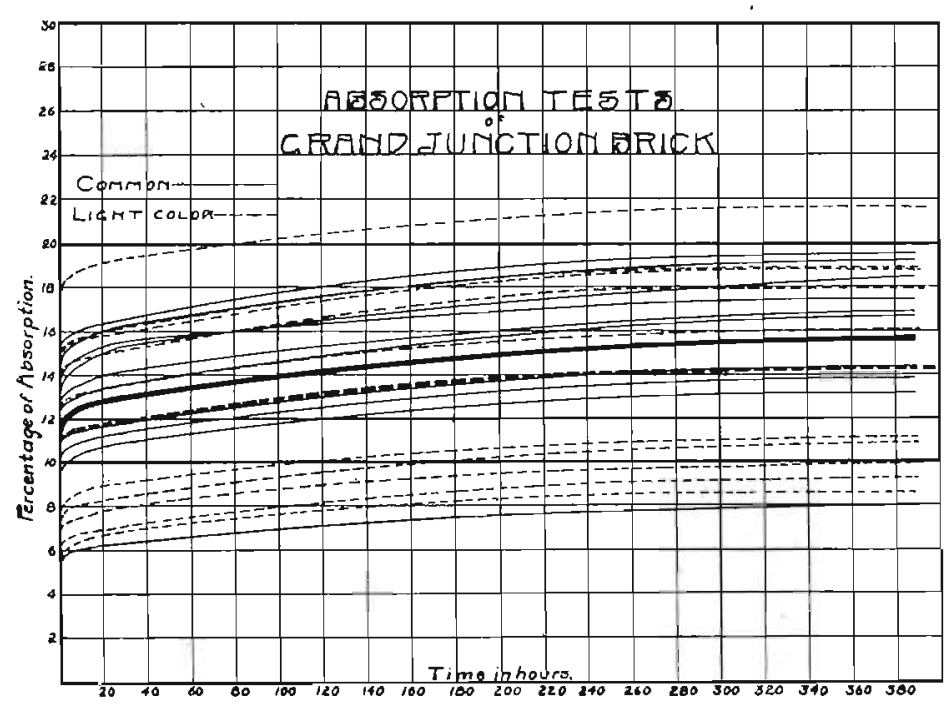

Fir. 96. Absorption tests, Grand Juuction brick. 
mon:" were cinite well burned, and of al uniformly red color, and of fairly uniform structure, although not so heavy and hard as the Webster City brick. Those Dale brick hereinafter designated "soft," were like the others except for being under burned, andi in fact too soft for any use excspt the interior filling of walls.

The Grand Junction brick were also selected as fairiy representative of some shipments for the backing of the walls of the

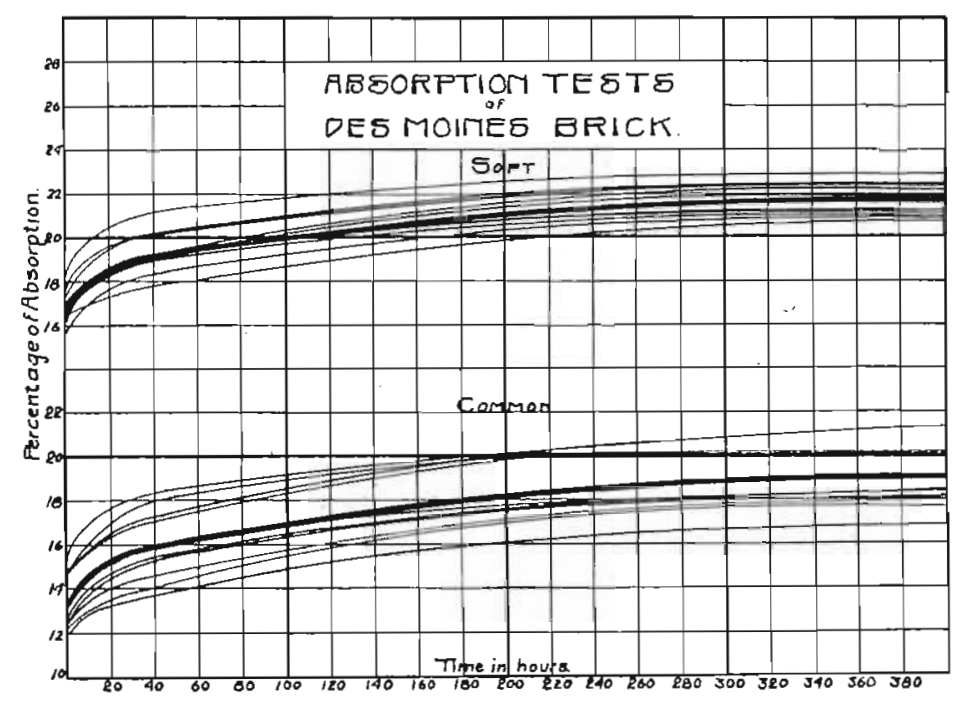

Fig. 97. Absorption tests, Des Moines brick.

Engineering Hall, and were also stiff mud, side cut brick. They were small but heavy for their size, and were made of a clay which burns to a light color, so that the lighter colored brick are the harder. The color in broken sections was quite inregular, some specimens, for wample, showing a light colored external layer, then a reddish larar, and them a dark colored, blue or drab core. The color varied greatly with the different brick, however. The brick were small but heavy for their size, and quite hard. They showed some lamination. Two sets of tests 


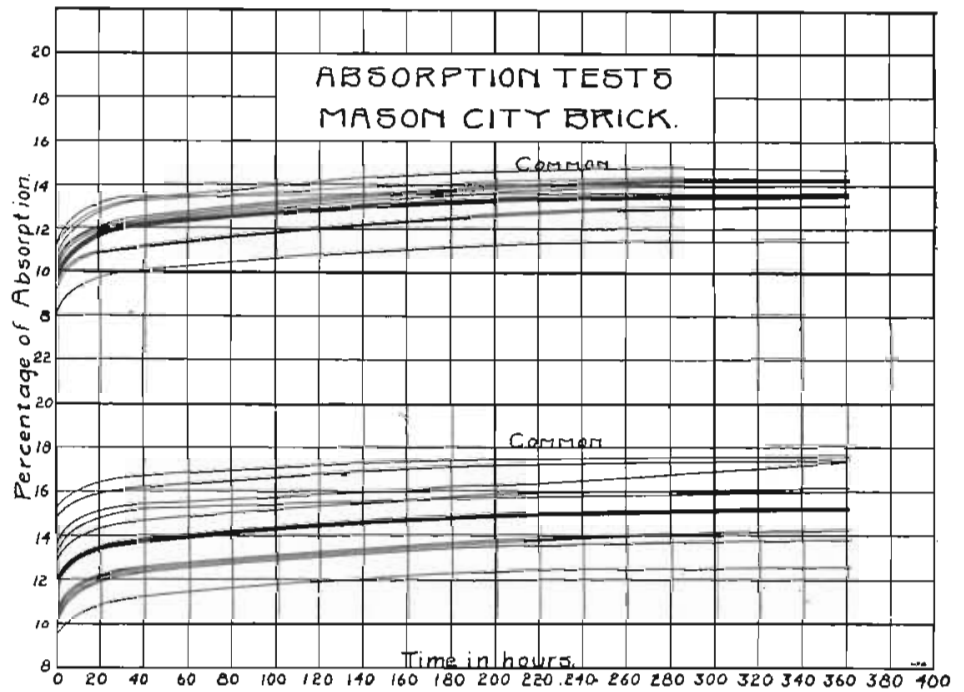

INs. y3. Absorprion tesis, Mason City brick.

were made of these brick. The specimens of the two sots were sot widely different in character, thougl probably the set marked light colored were on the averago a little better burned. The Mason City brick were stiff mud, side cut brick, hard,

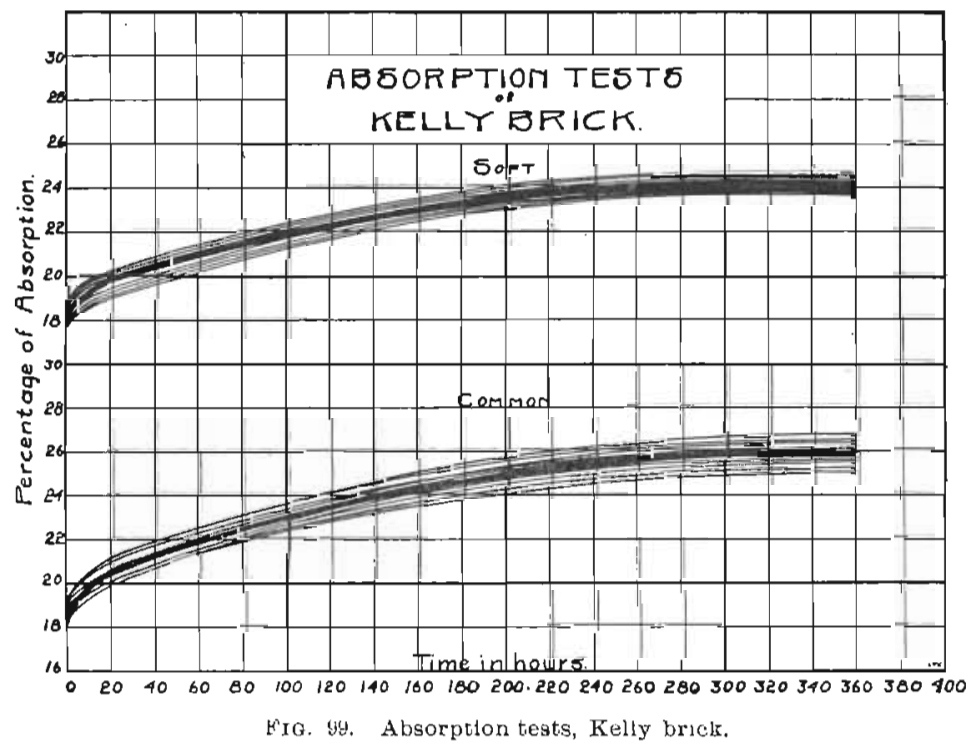




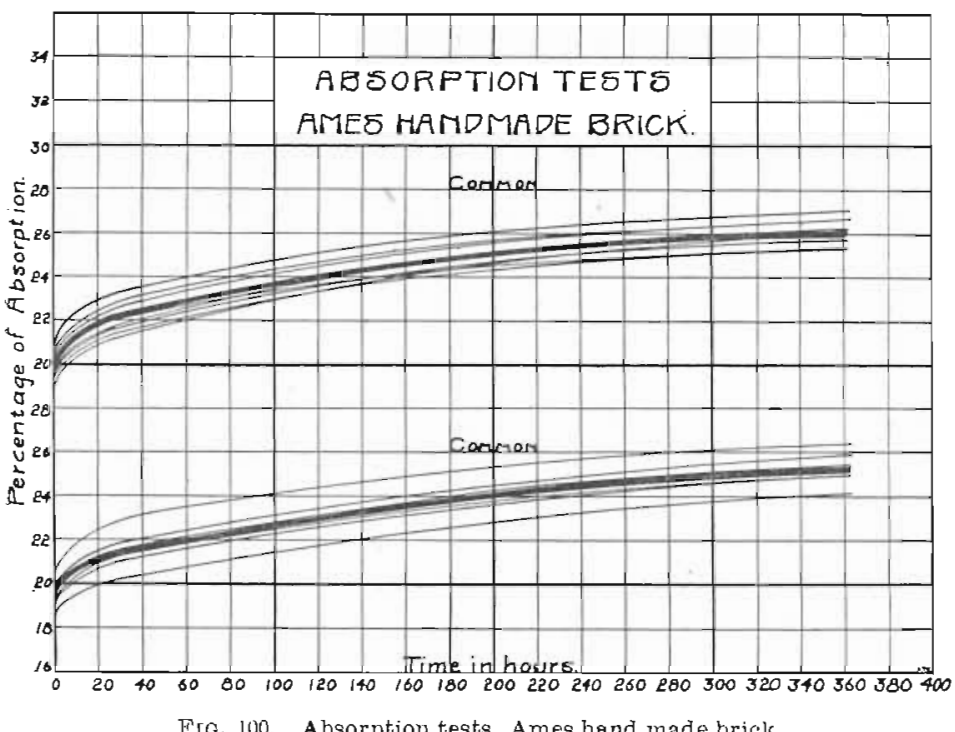

strong, heavy and moderately well burned. It was intended to test two grades, but when the brick arrived no very great difference could be detected, and the two sets of tests were on ahout the same grade of brick. These brick have a rather peculiar

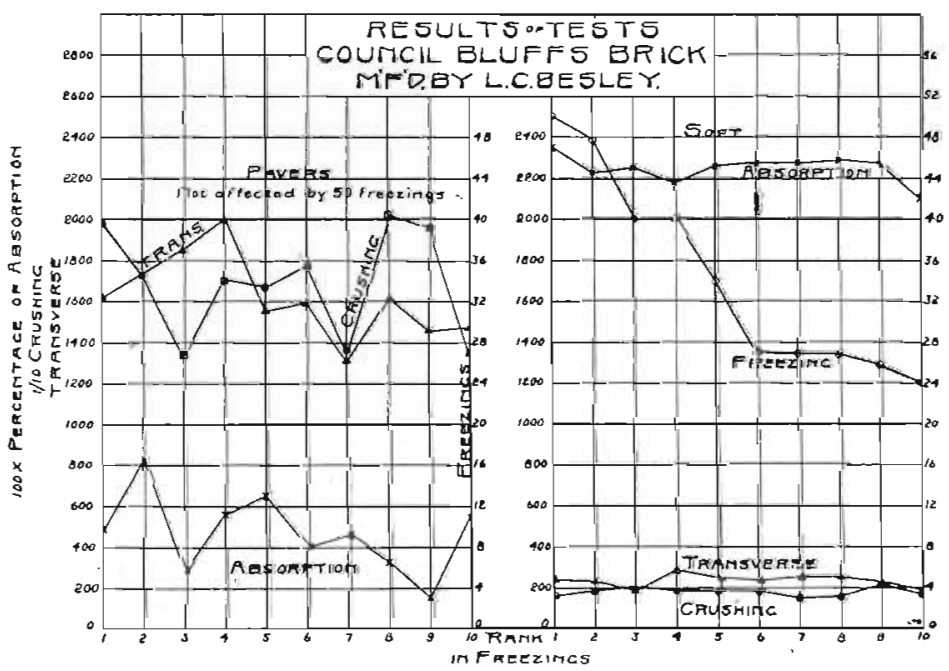

F'ra. 101. Comprehensive diagraxa of results of tests on Council Bluffs brick. 


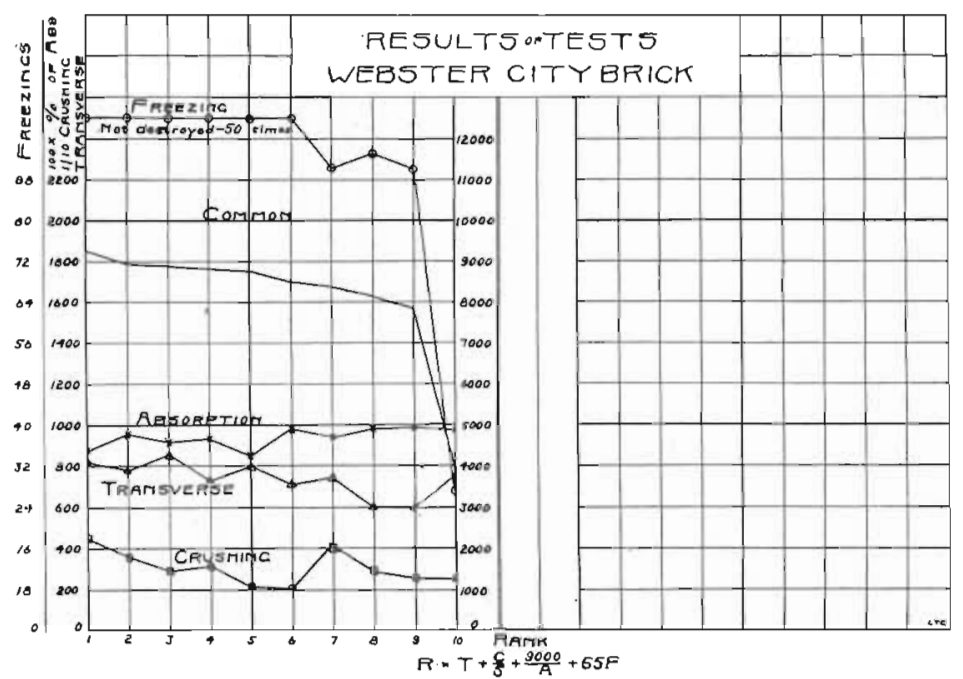

Fra. 102. Results of teste, Webster City brick.

structure. The material is evidently hard, strong, and durable, ont the interior of the bricli is badily laminated or fissured, up to rrithin a short distance of those sides and sends which bear against the die in the machine. All surfaces of the brick which wonld be exposed in a wall, therefore, have an external laver of

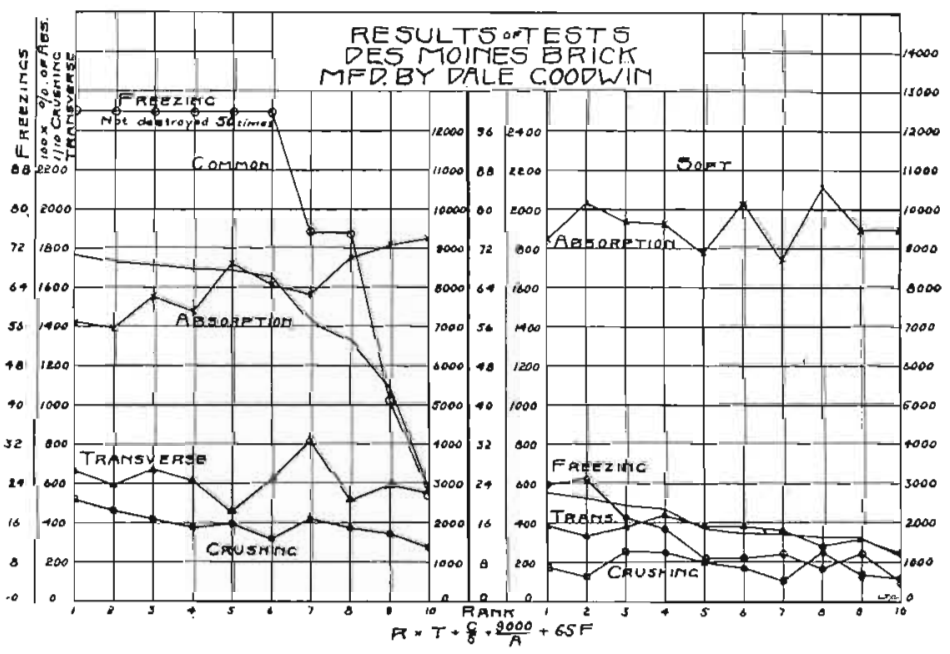

FiG. 103. Freezing tests, Goodwin brick. 


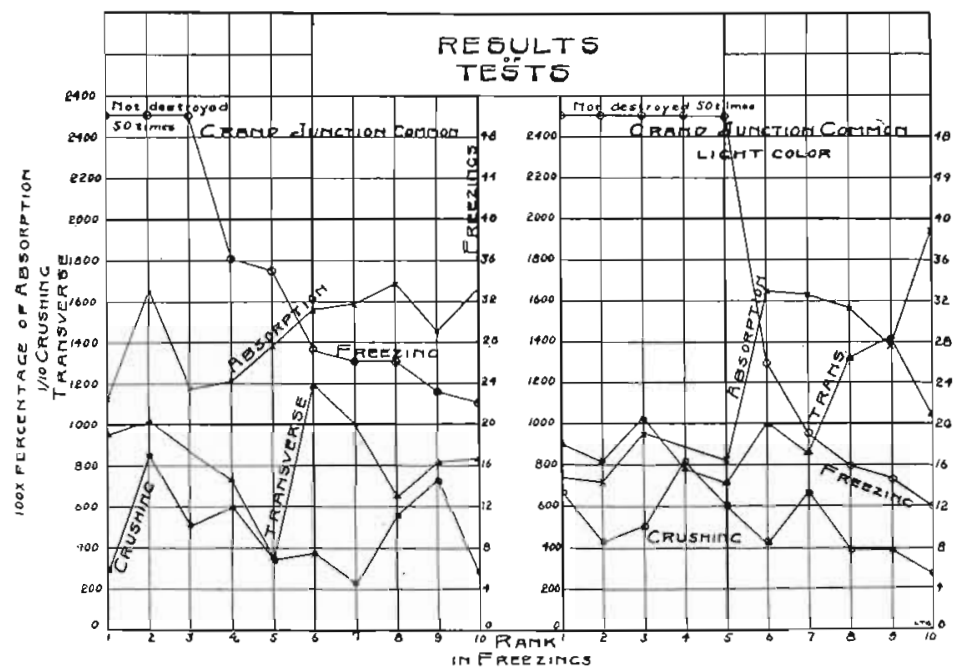

FIa. 104. Comprehentive diagram, Grand Junction brick.

extrai good material. The brick were fine-grained and fairly homogeneous. The common quite frequently contained nodules of caustic lime, and the scft also contained a few such nodules, but not so many as the common.

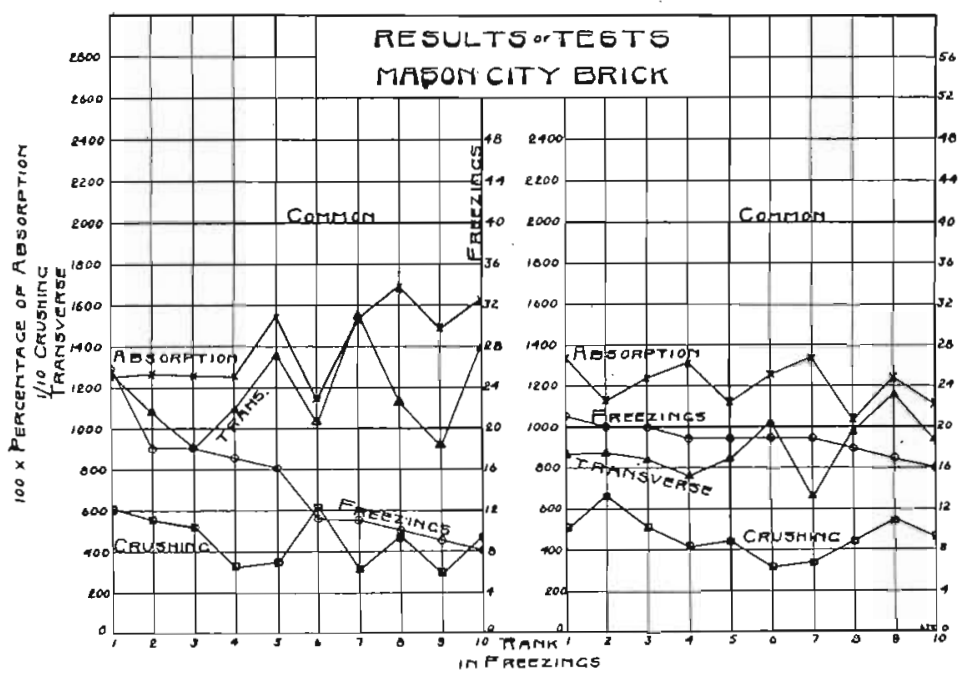

FIG. 105. Comprehensive diagram. Mason City briek. 
The Ames brick were tested as representative of the old fashioned hand made, soft mud bricls. The brick for the two sets of tests of Ames brick were selected from a pile delivered at a house near the college, as the yard is no longer operated. They prcbably represent about the best brick to be found in large percentage in the output of the yard.

RESULTS OF TRANSVERSE TESTS.

In figs. 90 to 93 , inclusive, the results of the transverse tests are given. It should be clearly understood that in these diagrams, as well as in all which are to follow, it is the "motulus of rupture," i. e., the tensile stress in the outer fibre at breaking, which is shown, so that the size of the brick cuts no figure. The point of main interest in connection with figs. 93-93 is the comrarison of the tensile strength of the brick when tested, first Aatwise, as laid in a wall, and second, edgewise as laid in a pavement. The diagrams show no very material difference exrept in two instances, the Mason City common brick, and the Council Bluffs pavers. In the first of these exceptions the strength per square inch edgewise was the greater, while in the second case the strength per square inch flatwise was the greater.

In the case of the Mason City brick it is easy to see why the edgewise position should give the ligher results, for in this the sound, extra good: layer's where the brick pressed against the die of the brick machine are put where they will do the most gocd, or farthest from the neutral axis. It will be remembered that the interior of these brick is badly fissured.

The Council Bluffs pavers were very hard burned, soft mud brick, and the defective side, the under side in thie molds of the brick machine, was placed on top in the flatwise tests; where it would be in compression, and where the defects would have the least effect. The only difficulty in accepting this explanation for the flatwise modulus of rupture being the greater in this 


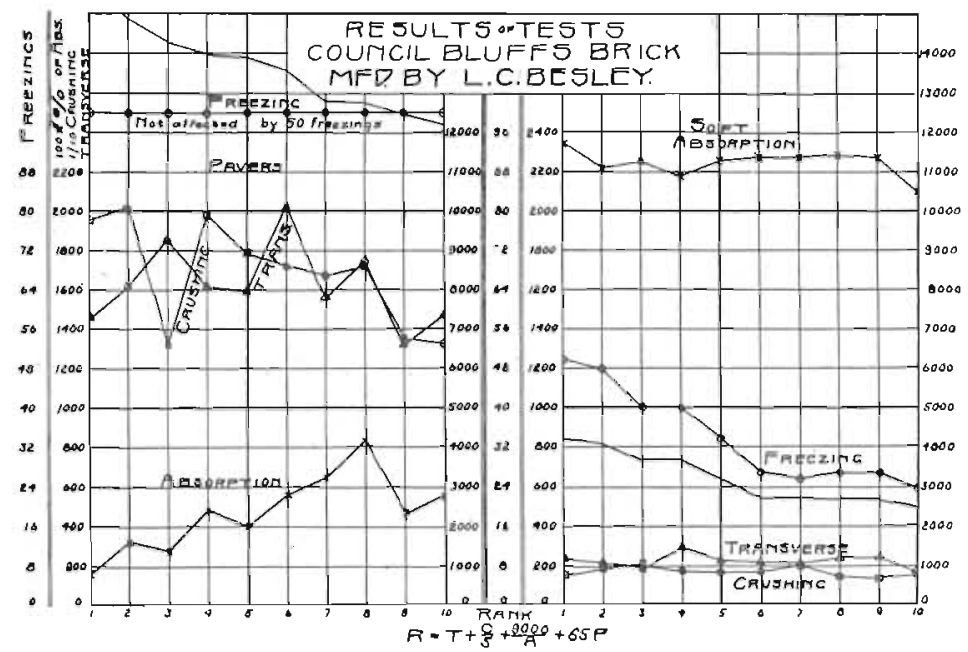

Fro. 103. Compreheustve diagram, Council Bluffs brick.

case is that we do not find the rule to hold true in the case of the soft Council Bluffs brick, nor in the rasc of the Ames hand nuade brick. Possibly the very hard burning of the Council Bluffs pavers made the defects, as would be tho case with glass, very moch more important as affecting the tensile strength.

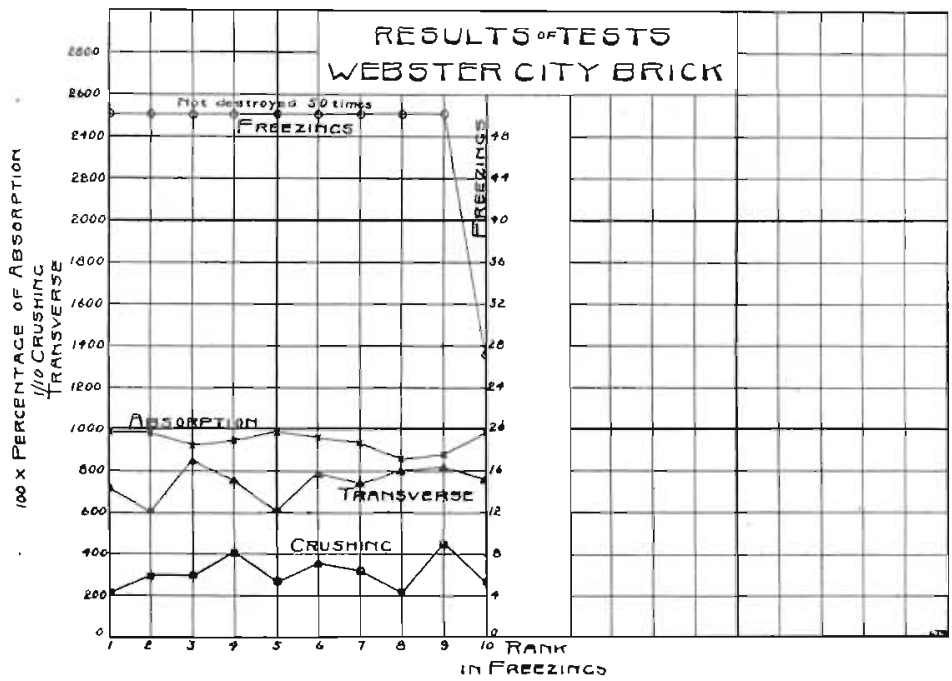

Fig. 107. Comprehengive diagram, Webster City brick. 
From the results of these tests we may conclude that in transverse tests of common brick sometimes the edgrwise and somctimes the flatwise position gives the greater modulus of rupture, depending on the structure of the brick, and that usually there is no very material difference.

In the diagrams which follow the modulus of rupture is from the flatwise tests.

RESULTS OF ABSORPTION TESTS.

In figs. 94 to 100, inclusive, the detailed results of the absorption tests are given. From these it is seen that when an inch cube of brick is immersed in water the absoption is at first very rapid. Within thirty minutes a large proportion of the total water eventually absorbled by the brick has been taken up. After this the rate of absorption proceeds at a continually diminishing rate until a periodi of from four or five up to: thirty hours after the first immersion. After these initial periods a slow, steady, and very slowly decreasing additional absorption of water continues, which in nearly all the specimens was still going on after a lapse of two weeks.

Herein the brick are compared on the basis of forty-eight hours immersion. Although the final results would be ten per' cent to fifty per cent greater, those for forty-eight hours were chosen because: first, the final per cents of absorption could not be obtained in, any practicable test period; second, the fortyeight hours points on the absorption curves gave fair points for comparison, far enough remcved from the starting points to be free from the irregularities where the curves bend rapidly; third, the water absorbed readily at first is of most importance, for brick are not usually so placed in structures as to berorne saturated with water, but ther simply absorb part of what water is dashed against them by the storms.

As has already bon indicated ten bricks were taken for each of the thirteen sets of tests made, and in each set of tests 
each of the ten brick was subjected to each of the four trists, transwirse strength, crushing strengtle, absorption, and freczing and thawing. In figs. 101-117, inclusive, the reults of all these tests are shown. In further explanation it should he said that the transicrs: and "rushing strengths are giveu in pounls $1 . r$ square inch, that the percentage of abeription is for lcrty-eight hours immersion of one inch, smooth cubes, and that the number of freezings platted is the number required to completely denclish a one-inch smootlu cuhe saturated witl water, the minimum freczing temprature bing about two degrees above zero Fahrenheit.

RESULTS OF FREEZING TESTS,

Thu following should also be particularly moted in connection with the freezing tests. All ten of the Council Bluffs paver's I'mained practically unaffected at the end of fifty fromings,

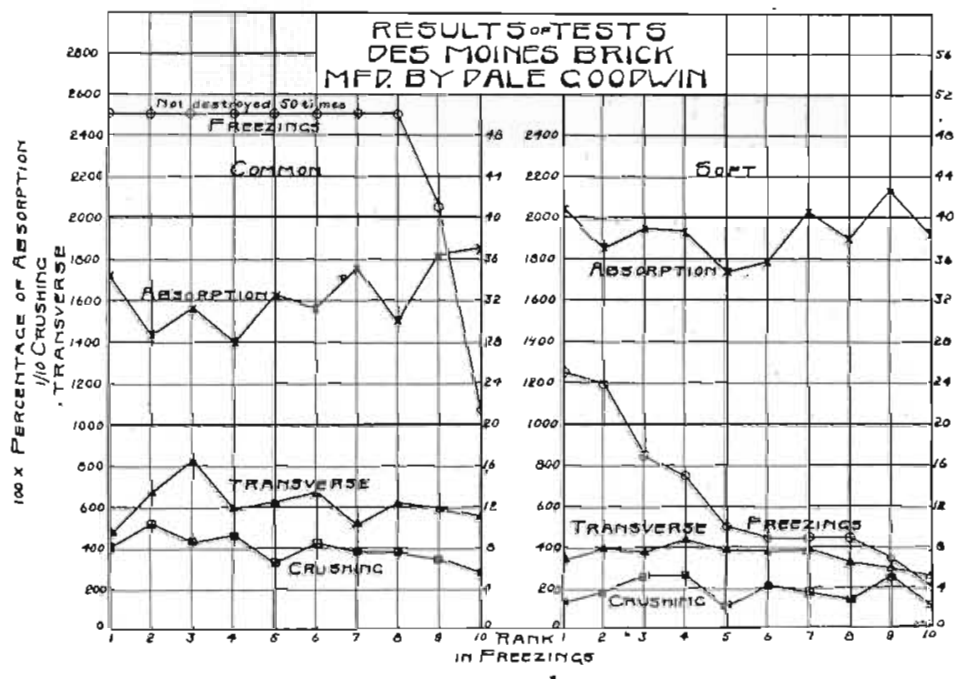

FrG. 108. Comprehensive diagram, Goodwin brick.

which was the number given all briek not demolished sooner. Of the Webster City specimens nine were not yet broken up: and laad lost only a small fraction of one per cent of their 
original weights. Of the ten Dale common brick, six were not appreciably affected, one lost only 0.9 per cont and one $12 . \pm$ ner cent. Of the ten Grandi Junction brick, in the first set, one was very slightly affected, and two others lost respectively 0.8 $y^{*}{ }^{*}$ cent and 13.6 per cent. In the second ten, two were verr little affected and three lost respectively 2.6 per cent, $6.3 p^{\circ} \times 1^{\circ}$ cent and 8.8 per cent. One of the surprising results of the trists described in this paper was that of the ten Kolly sol't brick, thuee were not appreciably affected and one other was not demolislıed,

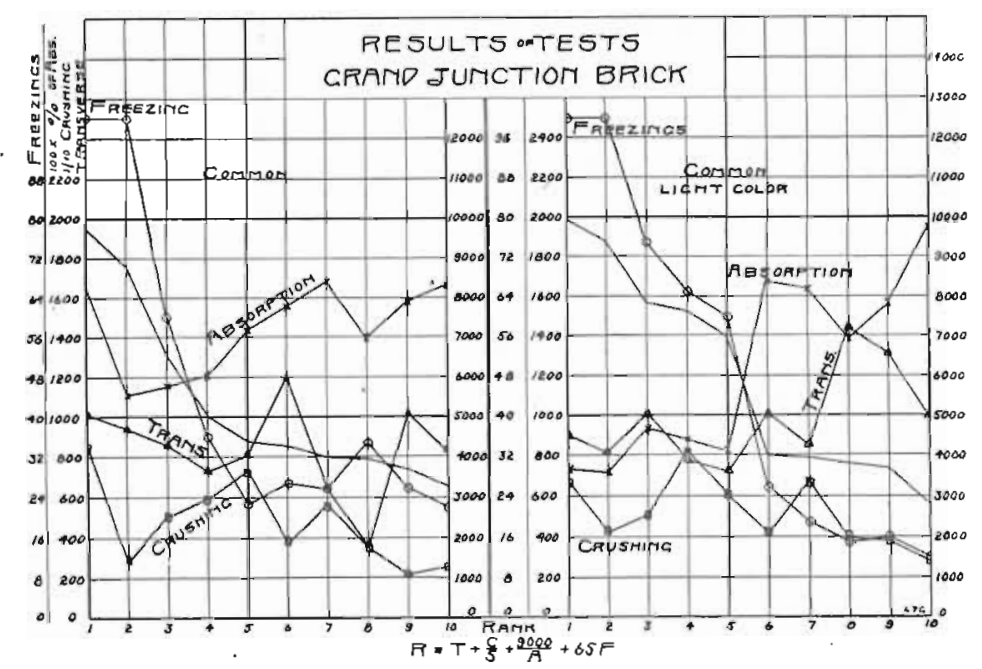

FTa, 108. Comprehensive diagram, Grand Junction brick.

though it lost 13.3 per cent of its weight. One of the second ten Ames hand made brick lost on]y 1.2 per cent.

In the diagrams those brick which were practically uniffected by fifty freezings were given an arbitrary rating: of 103, and for the partially demolished culses an approximate estimate was made of the number of additional freczings which would be required to totally demolish them. Of course this renders the alosulute values jhatted for part of the freczing tests unreliable, but thre is no uncertainty in the comprative results. 
COMPARISON ON TESTS MADE.

In ar'anging all of these diagrams the ain kept in mind, in addition to showing the results in detail, was to so allange the clata that comparisons could be readily made between the results of the different kinds of tests. It was desired to as"crtain conclusively whether the strongest brick would always luave the lowest percentage of absorpticn, and cspecially whether it would always prove the most durable when exposed to freezing and thawing. In figs. 101 to 105, inclusive, the brick in each set of tests are arranged in the order of their resistance to freezing and thawing. In fig. 112 the average results for all ten brick of each set of tests are arranged in the order of transverse st."ength, and in fig. 113 in order of resistance to freezing and thawing.

By a caretul study of the above diagrams some general corresipondence between the results of the diffierent tests can be traced, especially between the transverse, crushing and absorption tests, as evidenced by fig. 112, but this correspondence is only in a very general way and is subject to very many and very inregular exceptions. It is usually true that a very good brick will test better than a very poor bick in all four wars, as is seen by comparing; the Council Bluffs pavers with the Council Bluti's soft, or the Dale common brick with the Dale soft, for example; but when different kinds of common brick are tested it very frequently happens that the stronger brick may not resist freezing so well as the weaker brick, and sometimes the whaker may also have a lower per cent of absorption.

To properly rank brick from the results of tests evidently requires some method which can properly take into account the results of all the tests. When wo come to a consideration of this subject the question at once arises, what constitutes the value of a particular kind of brick? Obviously many things con- 
tribute which are not subject to test, as, for example, regularity of form, smoothness of exterior, beauty of color, freedom from efflorescence. Thu qualities usually tested are strength, both transverse and crushing, and porosity. In this investigation the dunaility when cxucsed to freezing, has also bizen tested.

Of these three qualities strength is undoubtedly a verer inportant quality, for a principal functicn of any wall is to carry weight, and the strength of a wall will depend upon the strengtl of the brick of which it is made. The transworse strength

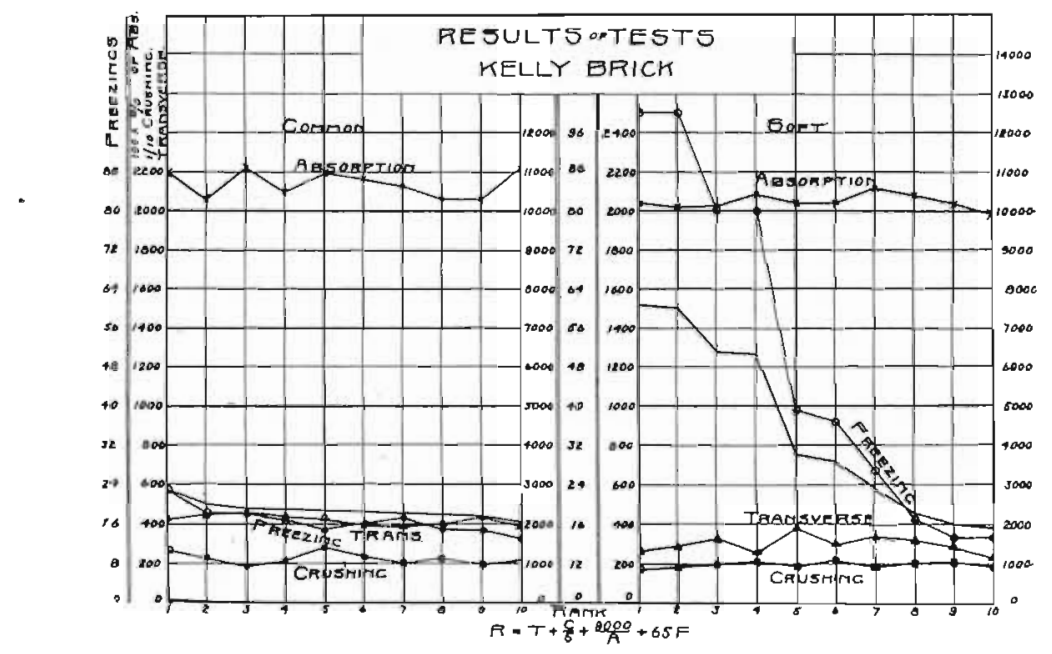

Fra. 110. Results of tests, Kelly brick.

as well as the crushing is of importance, for unsightly crarks due to uneven settlement are common and there is danger of racks of individual brick due to imperlect bedding. The strength of the bond will also depend largely on the transverse strength of the brick.

The absorptive power of a brick is also important but not so much so as the strength. Tyon the absorptive jowor nust depend in a measure the liability to discoloration from dirt, and the more absorptive the brick the greater clanger to the mortar from suction before it sets. 
Undoubtedly for brick used in this climate the most important cuality subject to test is the durability when exposed to freezing and thawing. It is seldom that walls fall by crushing under too great weight, while on the exterior of almost any building made of common brick a close search after a few years' exposure to our climate will disclose some evidences of disintegration.

The weight to be assigned to each of the qualities enumerated above will depend upon the use to which the brick are to be put. For example, in an interior pier not subjected to freezing at all but carrying a very heavy load, strength would be the all important quality. In other cases the resistance to freezing and thawing may be all important, and in fact is usually much more important than auy other cuality subjected to test. On the whole it seems fair to give strength twice the weight given to the results of the arewrition test and to give the freezing and thawing test a weight equal to all of the other tests combined.

In order to prepare fomula embodying this it is necosiany to know what are the average ratios between the rosults of the diffcrent kinds of tests. For the brick tested in these experiments the results are shown in the following table: 
TABLE SEOWING COMPARATIVE RESULTS OF BRICK TESTS.

\begin{tabular}{|c|c|c|c|c|c|c|c|c|c|}
\hline Kinc & 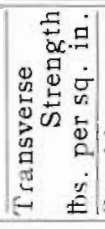 & 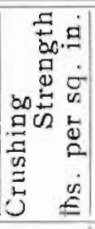 & 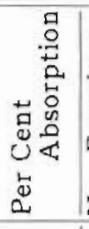 & 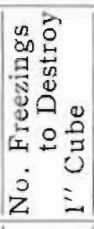 & 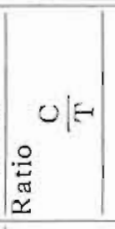 & 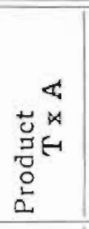 & $\underbrace{-4}_{3}$ & 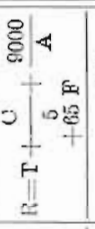 & 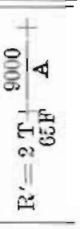 \\
\hline & $\mathrm{T}$ & C & A & $\mathrm{F}$ & & & & & \\
\hline & 1620 & 16800 & 4.7 & 100 & 10.4 & 7600 & 16.2 & 13409 & 11700 \\
\hline $\begin{array}{l}\text { Webst } \\
\text { Com }\end{array}$ & 740 & 3060 & 9.5 & 90 & 4.1 & 7000 & 8.2 & 8100 & 8300 \\
\hline Dal & 610 & $3: 00$ & 15.4 & 81 & 6.4 & 9400 & 7.5 & 7200 & 7100 \\
\hline $\mathrm{Col} . \mathrm{Co}$ & 990 & 5180 & 12.3 & 40 & $5.2^{1}$ & 12200 & 20.3 & 6000 & 5900 \\
\hline $\mathrm{C}$ & 840 & 4720 & 135 & $45 / 2$ & 5.6 & 11300 & 18.5 & 5400 & 5300 \\
\hline Ave & 910 & 4950 & 12.9 & 47 & 5.4 & 11700 & 19.4 & 5790 & 5600 \\
\hline Kelly Soft & 300 & 1930 & 20.5 & 51 & 6.4 & 6200 & 5.9 & 4400 & 4300 \\
\hline Mason City Con & 890 & 4660 & 12.1 & 19 & 52 & 10800 & 47.0 & 3800 & 3800 \\
\hline Mason City Common & 1170 & 4460 & 13.8 & 15 & $38_{1}$ & 16100 & 78.0 & 3700 & 3000 \\
\hline Mason City Average. & 1030 & 4560 & 93.0 & 17 & 4.5 & 13100 & 60.6 & 3700 & 3800 \\
\hline Council Blufts Soft... & 239 & 1790 & 22.6 & 34 & 7.8 & 5290 & 68 & 3200 & 3100 \\
\hline Ames Common .... & 280 & $15: 0$ & 22.7 & 31 & 5.4 & 6300 & 9.0 & 3000 & 3000 \\
\hline Ames Con & 230 & 1470 & 21.8 & $27 / 2$ & 6.4 & 5000 & 8.4 & 2700 & 2700 \\
\hline & 250 & 1490 & 22.3 & 29 & 5.9 & 5600 & 8.6 & 2800 & 2800 \\
\hline Kelly Com & 420 & 2240 & 81.4 & 17 & 5.3 & 9000 & 24.8 & 2400 & 2400 \\
\hline Dale Soft... & 360 & 1830 & 19.3 & 13 & 5.1 & 6900 & 27.8 & 2000 & 2000 \\
\hline Average 6 Comwon. & 660 & 3370 & 15.7 & 47 & 5.3 & 9400 & 21.5 & & \\
\hline Average 3 soft .... & 300 & 1850 & 20.8 & 33 & $\begin{array}{ll}64 \\
\end{array}$ & 600 & 13.5 & & \\
\hline
\end{tabular}

It will be seen that some of these ratios are subject to wide fluctuations and the average values axe not to be taken as yet well established by the results of this single sorics of tosts.

RATING TORMULA.

For a rating formula whose cofficients are approximately determined, we may talie, however,

$$
\mathrm{R}=\mathrm{T}+\frac{\mathrm{c}}{5}+\frac{9000}{\mathrm{~A}}+65 \mathrm{~F},
$$

In which $\mathbf{R}$ is a ranking number. 
T-Transverse modulus of rupture in pounds per square incll.

C-Crushing strength in pouds per square inch.

A-Per cent of absorption in forty-eight hours immersion.

$\mathrm{F}$-The number of freazings reguired to demolish a one-inch sinouth cube.

In figs. 106 to 1.1, inclusive, the results of the individual tests are arranged according to this formula, and in the later diagrams the average results of each set of tests are amranged in similar manner. Of course the tests correspond much more nearly to the rank when arranged in this way than in figs. 101 to 105 , for the results of the tests are taken into account in making the arrangement.

This subject is one whicl deinands considerable further investigation.

Crushing tests are difficult and expensive. In case they have not been made the transver'se strength may be given double weight, making the formula.

$$
\mathrm{R}^{\prime}=2 \mathrm{~T}+\frac{9000}{\mathrm{~A}}+65 \mathrm{~F},
$$

In the above table the values of $R^{\prime}$ are also given and it will be seen that they rank its brick in the same order: as $\mathrm{R}$.

Attention is called to the results of the freezing test in the case of the Mason. City brick and the Kelly brick. In the case of the Mason City brick it is undoubtedly true that the results cf the freezing test did not corrcetly indicates the durability of the brick as they are commonly used in walls.

The structure of these brick has already been discussed and it will be remembered that the interior is considerably fissured, while the exterior surfaces which are uxposed to the weather are smoth, dense and hard, and not fissured. In the fireezing test the brick are saturated with water taken into the interior fissures, whereas wben laid in a wall the brick could not absorb much water on account of the dense, hard exterior skin. 


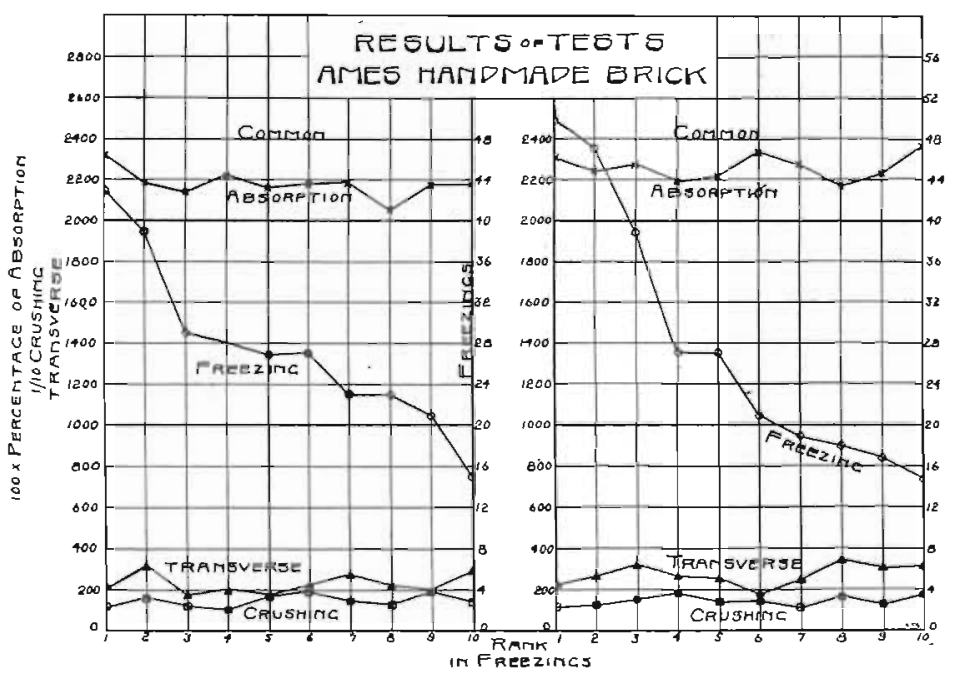

FrG. 111. Results of tests, Ames hand made brick.

In the case of the Kally brick it was a very surprising thing. t]at the soft brick tested better than the well burned brick as regards the per cont of absolption and especially as regards the resistance to freizzing and thawing: It is very difficult to ex-

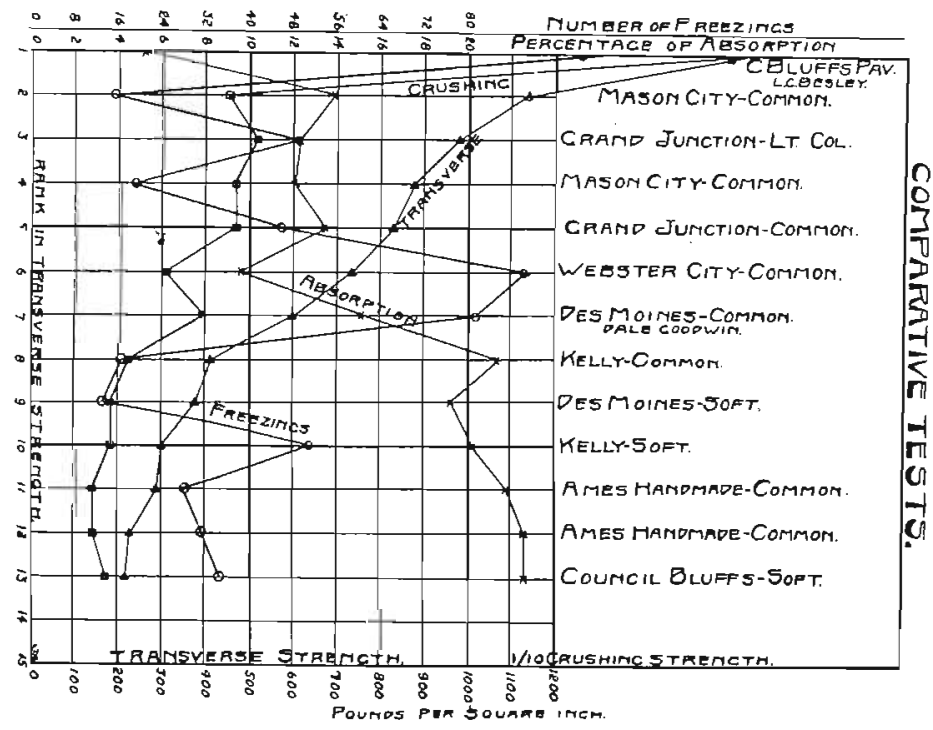

FIG. 112. Diagram showing comparative results of tests. 


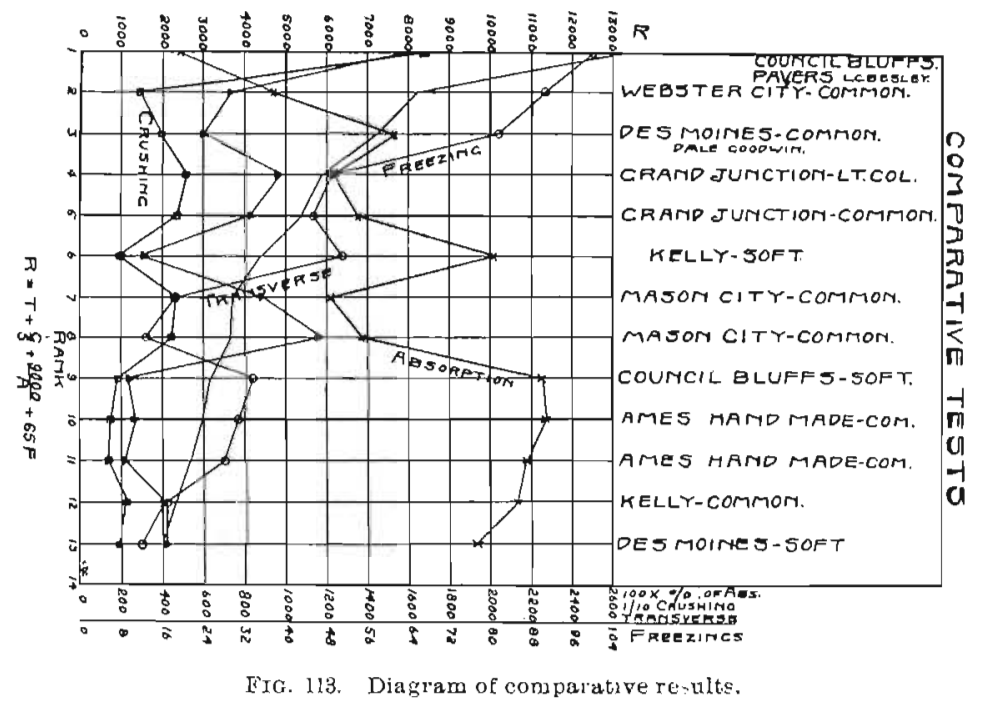

whain why this should be the case for the soft brick were pale and apparently not so well burned as the common brick. The only explanation which can be given by the author is perhaps that the olay of which the soft brick were made was taken from a different place in the pit and was of much better material than that from which the common brick were made. There is some in-

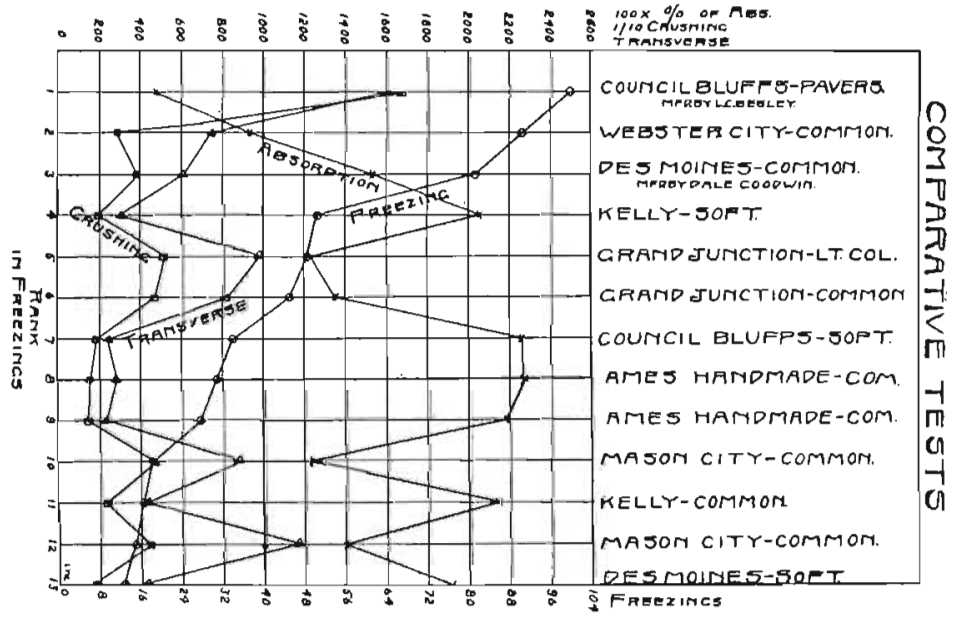

Fig. 1LA. Diagram of comparative results. 
dication of this in the brick, for the common brick showed many more nodules of lime than the soft brick.

\section{Tests of Strength of Hollow Building Blocks.}

ADVANTAGES OF HOLLOW BLOCKS.

During the last few year's there has heen an extensive develcliment in the manufacture and use of loollow clay blocks in place of solid brick for building construction. These blocks liave some stricng advantages in competition with brick. One is the saving in weight, which leads to economy where the material must be transported long distances. In the walls themselves the saving in weiglut may often be of great importance as it lessens the leads on the other parts of the building and on the founclations. Another very important advantage of hollow blocks is in the air space in the walls due to the hollow spaces in the blccks. These secure much drier walls. Another advantage is the larger size of the blocks, which permits greater rapidity in lasing, and makes a much smaller number of joints. Of course the greater disadvantage of brick masonry as compared with stone masonry is in the much larger number of joints imperfectly filled with mortar through which cold air may find its way.

However, hollow blccks have not been used a sufficient number of years to thor'ughly dmonstate their merits and it often becomes difficult to secure their use. The principal objection which is raised to them is their lack of strength as compared with solid brick. There is no doubt that hollow blocks are much wealser than solid brick and that lhollow! block walls are much weaker than walls constructed of solid brick. This chjoction is so strongly urged that it sometimes prevants the use of hollow blocks in places where they would otherwise be adopted. 
TESTS OF HOLLOW BLOCKS.

During the past few years several tests of tho strength of hollow blocks have been made by the civil ongineering department of the Iowa State College and for the information of manufacturers and users of building materials they are gronped in the table given below. All the tosts were made by imbedding the building blocks in plaster of Paris in the 100,000 pounds testing machine of the engineering division at Anos. The blocks were imbedded in plaster of Paris hith at the top and the bottom and the plaster of Paris was allowed to sut usually oval niglut. An adjustable top bearing was used to enable the machine to adjust itself to lark of parallelism of the top and bottom.

TABLE SHOWING TESTS OF IOWA HOLLOW BIOCKS.

\begin{tabular}{|c|c|c|c|}
\hline MANUFACTURER. & 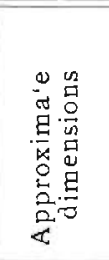 & 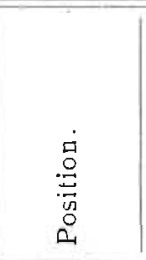 & 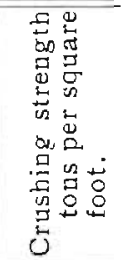 \\
\hline Capital City Br.ck and Pipe Co., Des Moines, lowa. & $\begin{array}{l}4 \times 8 \times 12 \\
4 \times 8 \times 12 \\
4 \times 8 \times 12\end{array}$ & $\begin{array}{l}\text { Flatwise } \\
\text { Endwise. } \\
\text { Edgewise }\end{array}$ & $\begin{array}{l}78.1+^{*} \\
230.8 \\
171.5+^{*}\end{array}$ \\
\hline Mason City Brick and Tile Co., Mason City, Iowa. & $\begin{array}{l}4 \times 8 \times 12 \\
4 \times 8 \times 12 \\
5 \times 5 \times 12 \\
4 \times 4 \times 12\end{array}$ & $\begin{array}{l}\text { Flatwise. } \\
\text { Edgew se } \\
\text { Flatwise. } \\
\text { Flatwise. }\end{array}$ & $\begin{array}{l}64.0 \\
59.6 \\
39.1 \\
56.5\end{array}$ \\
\hline Sioux City Brick and Tile Co., Sioux City, Iowa .... & $\begin{array}{l}5 \times 8 \times 12 \\
5 \times 8 \times 12\end{array}$ & $\begin{array}{l}\text { Flatwise. } \\
\text { Edgewise }\end{array}$ & $\begin{array}{l}30.2 \\
65.0\end{array}$ \\
\hline Johnson Brothers, Kalo, Iowa & $\begin{array}{l}5 \times 8 \times 12 \\
5 \times 8 \times 12 \\
5 \times 8 \times 12\end{array}$ & $\begin{array}{l}\text { Flatwise. } \\
\text { Endwise. } \\
\text { Edgewise }\end{array}$ & $\begin{array}{r}47.0 \\
131.0 \\
59.9\end{array}$ \\
\hline Des Moines Clay Manufacturing Co., Des Moines, Ia & $\begin{array}{l}5 \times 8 \times 16 \\
5 \times 8 \times 6 \\
8 \times 8 \times 16\end{array}$ & $\begin{array}{l}\text { Flatwise. } \\
\text { Flatwise. } \\
\text { Flatwise. }\end{array}$ & $\begin{array}{l}49.0 \\
5.5 .5 \text { - }^{*} \\
58.0 \mathbf{H}^{*}\end{array}$ \\
\hline
\end{tabular}

* Ealed to break at full power of testing machiue.

In stating the results given in the above table it may be said that architects allow five to ten tons per square foot pressure 
on brick masonry. Even if this usual prossure were adoptod witl hollow block walls a large factor of sufuty would evidently be secured. Of course in walls built of hollow bloclss piers of solid brick are usually built to carry concentrated loads ficom beans and trusses. It may be said that with proper precaution the strength of hollow blocks apuears ample for all ordinary building construction.

\section{Tests of Iowa Paving Brick.}

GENERAL CONSIDERATIONS.

The manufacture of paving brick constitutes a very important part of the manufacture of clay products in Iowa. Although the use of brick paving has been very extensive it began at a comraratively recent date, ant the standardizing and developing of the various tests of the matcrial is, even yet, in an matisfartory state. It cannot be said that the derelopment of satisfactory tests has kept pace with the use of paving brick.

In Towa the manufacture and use of praving brick developed ver rapidy in the few years following 1890, but, owing largely to uncrainties regarding the constituticuality of vaving laws, there has been a lull in the extensicn of briak paving until very recently. The construction of paving is now again developing. but the brick are coming into lien competition witì asplualt. Tho question of bick paving versus asplialt javing is one which has aroused bitter discussions in several Tcwa cities duning the last year or two, and it must be admitted that the use of asplialt l.as greatly imcreased recently in this state. It is easy to see why this slould be the case when consideration is given to the pleasing appearance, the smooth unbroken surfare and the complaratively noiseless character of the asplualt paving. 


\section{ADVANTAGES OF BRICK PAVING.}

It must be admitted that brick paving has many advantages as compared with asphalt cr any other form of paving, especially in the middle west, and there is practically no doubt that the construction of brick pavements will continue to be more extensive in the future. In the first place, brick is cheaper than asshalt, and this is an important consideration, especially in the cities of Iowa which have yet to construct pavements. Second, as is proven by recent tests by the civil engineering department of the Iowa State College at Ames, and by other experimenters, the traction on brick pavements is materially less than on asphalt, contrary to the common impression due to the smooth surface of asplaalt pavements. Third, brick pavements do not reruire so high a degree of professional skill for their repair and maintenance. It is an iuteresting question to consider what the smaller cities of Iowa which are putting in asphalt pavements at the present time will do: when the guarantee period exjires and they are thrown on their own resources, or the mercy of the large corporations to repair and maintain their pavements. F'curth, the methods of construction of good brick pavement and the materials and processes can be submitted to constant direct inspection and supervision, while with asphalt entire confidence must be placed in the contractor. Fifth, brick pavement is capable of withstancling successfully heavicr traffic than the asphalt, although this statement should be qualified by the statement that asphalt is suiter to much heavier traffic than it was formerly supposed it cuuld successfully stand. Sixtl, brick pavements are not so slipipery as asplalt lavements and can be constructed on much steeper grades.

PAVING BRICK TESTS.

The above extensive list of advantages insures that the manu-. facture and use of paving brick will continue to be extensive and 
important in the state of Iowa. Consequently, tests of the paving brick of the statio are cf great interest and value, if made sufficiently numerous and witl sufficient slkill and care. During the last four years the civil engineering department of the Iowa State College has been engaged in making: an extensive series of tests of Iowa paving: brick, in all over four thousand individual tests liaving: been made. The calculation, compilation and dischassion of these tests require a vast amount of labor, which has not yet been entirely completed, so that we are now able to give only a preliminary report of the tests. In the following diagrans the principal results of these tests may be seen in the most compact form possible.

The brick for thase tests were furnisled by the following manufacturing companies:

Capital City Brick and Pipe Comprany, Des Moines, Iowa.

Merrill Brick Company, Dess Moines, Iowa.

Iowa Brick Company, Des Moines, Iowa.

Flint Brick Company, Des Moines, Iowa.

Granite Brick Company, Burlington, Iowa.

Boone Brick, Tile and Paving: Company, Boone, Iowa.

Each of these companies was askied to furnish three kinds of brick: first, the best or No. 1 brick, which in these diagrams is designated by the subscript "A"; second, the overburned brick, which in these diagrams is designated by the subscript " $\mathrm{B}$ "; and third, the underburned or soft brick, which in these diagrams is designated by the subscript "C." In the diagrams, also, for the salke of avoiding a large amount of lettering the initial letter of the company's name is used to designate the brick. Hence the following is the key to the kinds of brick given on the diagrams: 
Capital City Brick and Pipe Company,

No. 1 brick

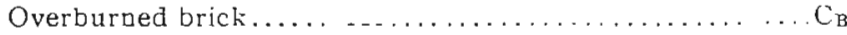

Soft brick $\ldots \ldots \ldots \ldots \ldots \ldots \ldots \ldots \ldots \ldots, \ldots \ldots \ldots, \ldots \ldots \ldots$

Merrill Brick Company,

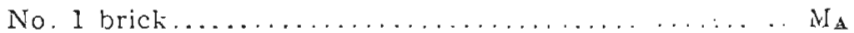

Overburned brick $\ldots \ldots \ldots \ldots \ldots \ldots \ldots \ldots \ldots \ldots \ldots \mathrm{M}_{\mathrm{B}}$

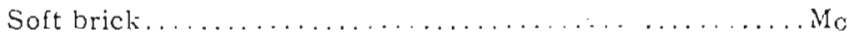

Iowa Brick Company,

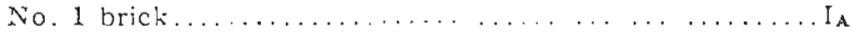

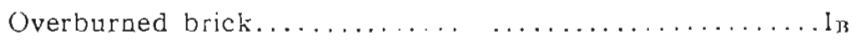

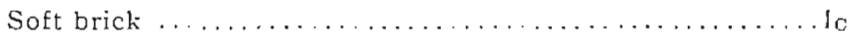

Flint Brick Company,

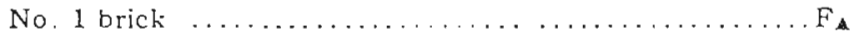

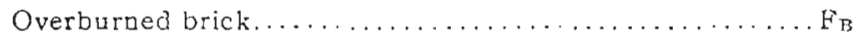

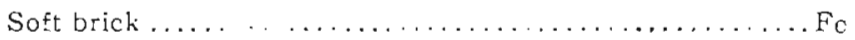

Granite Brick Company, (Burlington)

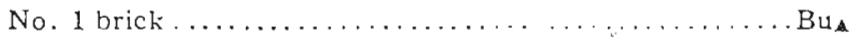

Overburned brick .......................... Bus

Soft brick............................. Buc

Boone Brick, 'Tile and Paving Company,

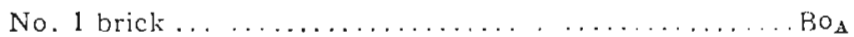

Overburned brick ........................ Bö

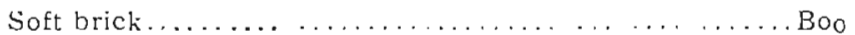

An examination of the diagrams will show as a very striking fact the great lack of unifomity uf the results of all paving brick tests. This sane lack of uniformity is encounteled by all careful experiments and is an indication ot colresponding variations in the propertios of the brick. It is evident, cn account of this lack of uniformity, that a large number of tosts should be made cf eaclu kind of brick to give results at all worthy of use. 


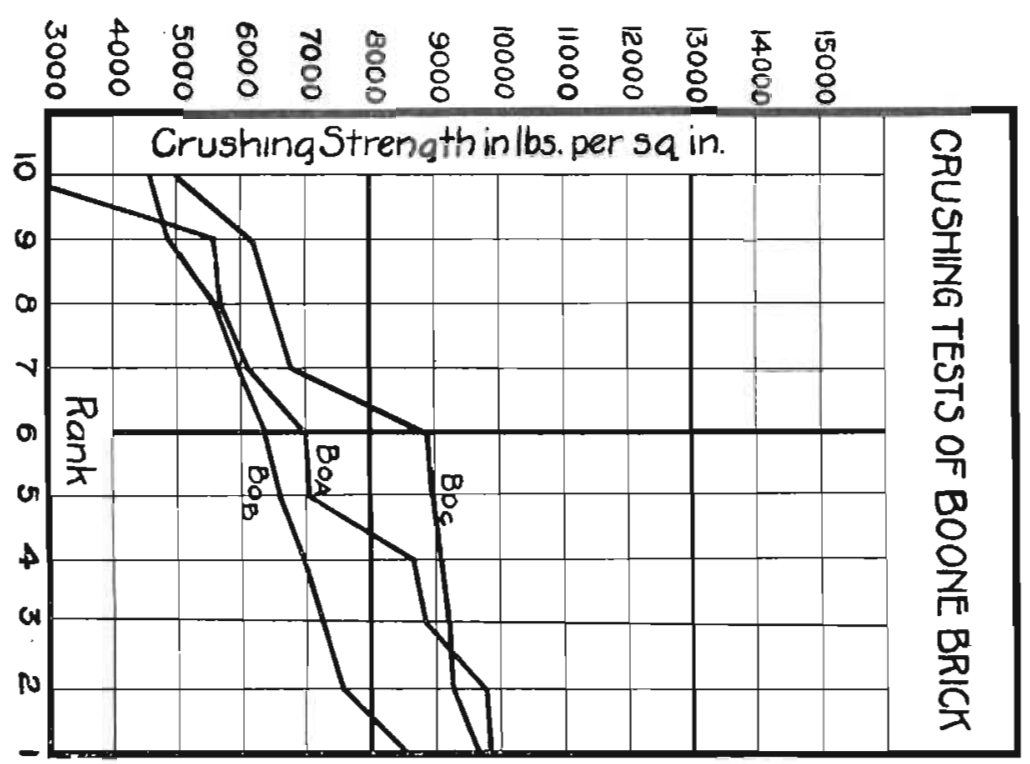

FIG. 115. Crushing teste, Boone brick.

The tests of paving brick which have been made in the past are four in number: the crushing test, the absorption test, the test of transverse strength and the rattler test.

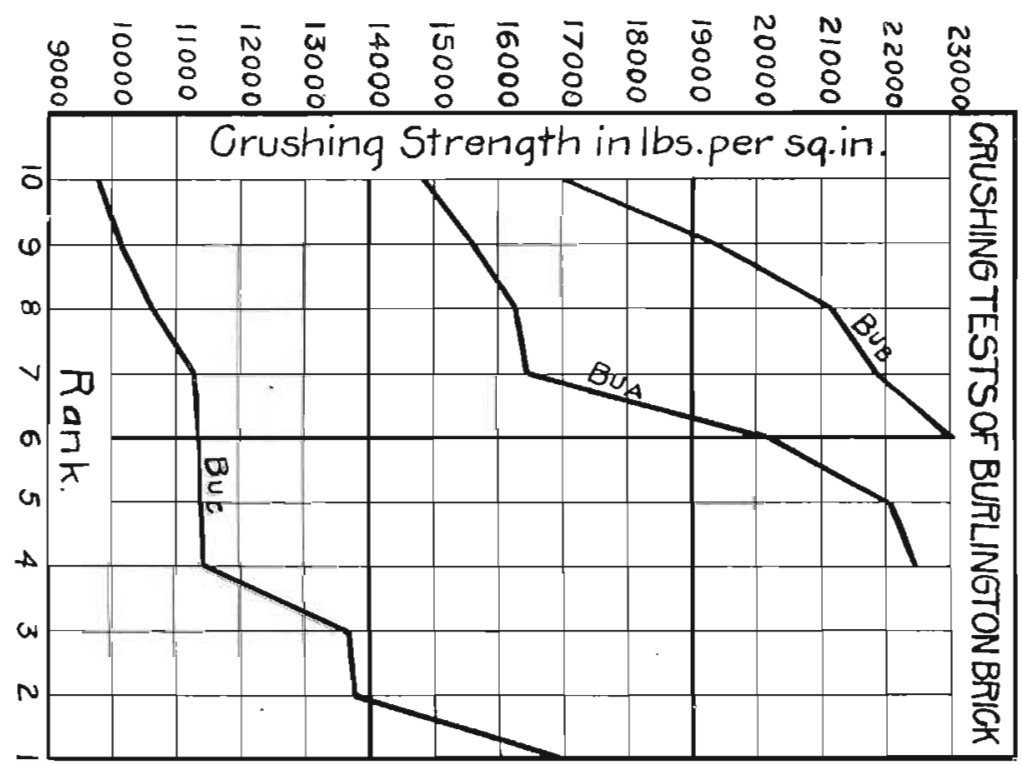

Fıa. 118. Crushing tests, Burlington brick, 
TEE CRUSHING TEST.

The crushing test of paving brick may be said now to have been abandoned by practically all experimenters. In the inres-
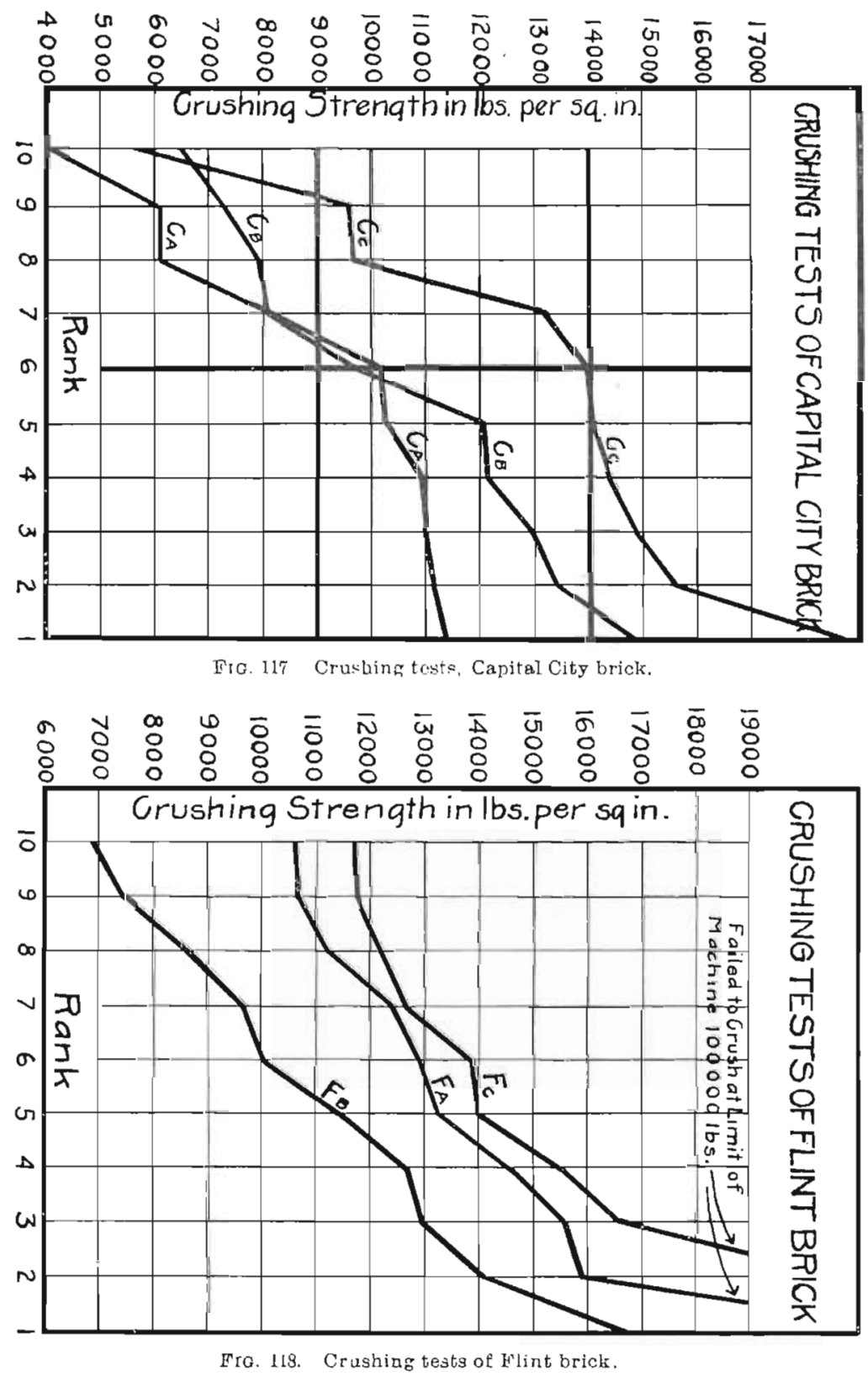
tigation now under discussicn crushing stungth was determined simply as a matter of scientific interest. Paving brick never fail in the street by direct crushing and, in fact, the crushing strength of Javing brick compares very favorably witli the strength of granite. The test is not abandoned becauso its results would be of no value cr interest, but because the same information can be secured by transverse tests in a muclu simpler and less expensive manner. The crushing test requires a very

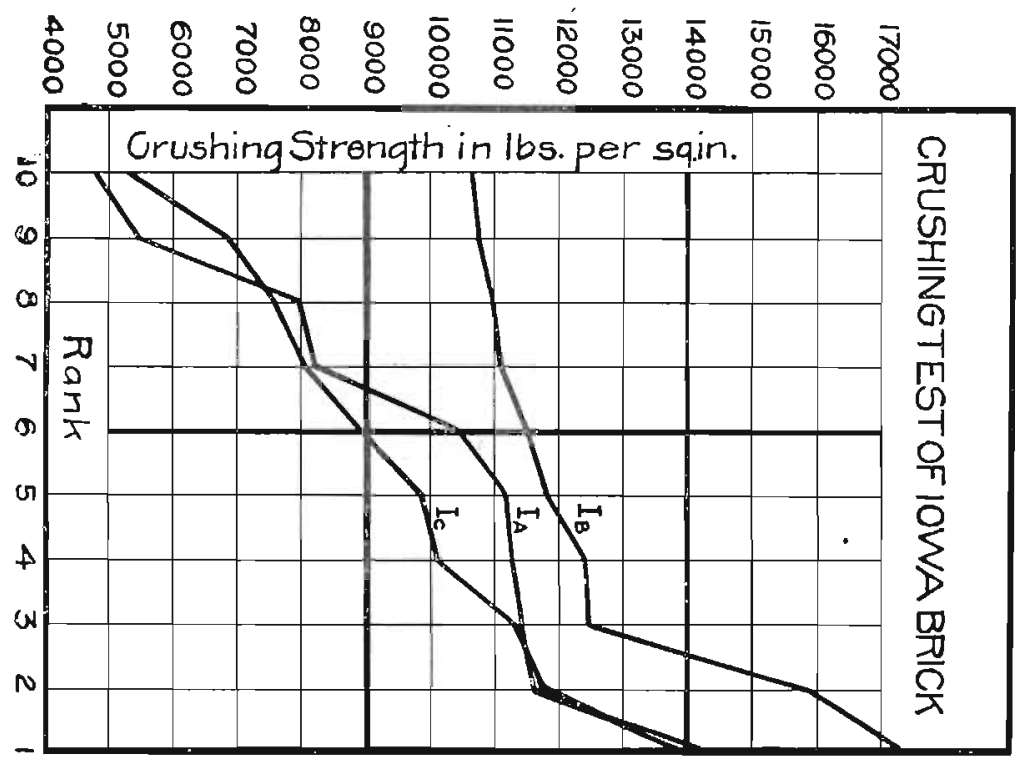

F o, 1.4. Crustring tests of Iowa brick.

powerful testing machine and it is difficult and expensive to prepare the specimens for the tests. All the crushing tests in this investigation were made of ends of brick previously brokien in the transvorse tests. These were shaped so as to: be paractically square in cross section. The upper and lower edges of the brick were made respectively the upper and lower bearing: surfaces in the tests. These bearing surfaces wore carefully ground to true planes and in the testing machine were placed immediately 
in contact with steel bearing plates. The upper bearing plate was adjustable to take care of lack of parallelism.

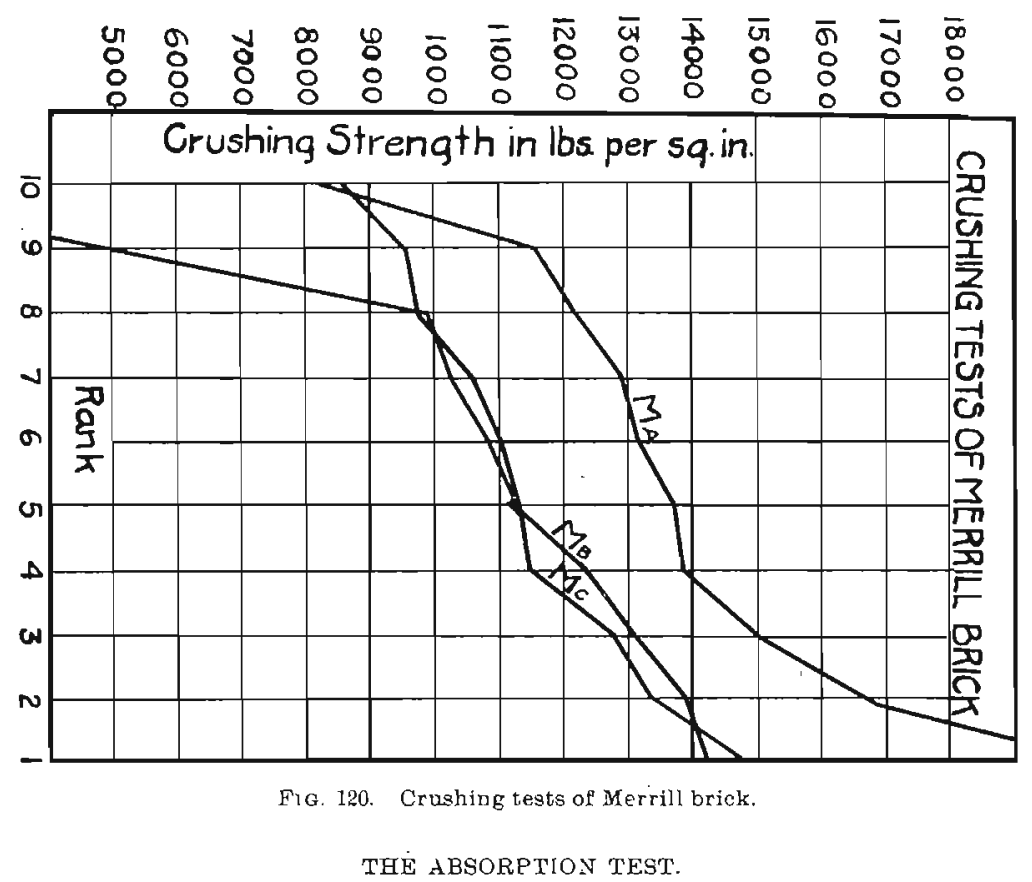

The absorpticin test of liaving brick is of value as showing the hardness cf hurning of the material. However, whem brick from. differeut localities, made from different materials, are compared, the alsorption test cannot be taken as a relative index of the quality, for some materials give a larger perecntage than others of absorption for the same degree of vitrification. The absorption test has been standardized by the National Brick Manufacturers' Association, and these tests have been conducted in accordance with their recommendations. The tests are made of brick previously tested in the rattler tests so that the outer skin is removed. These are first plarerl in the cven and dried for forty-eight hours, then soaked in water and the pri: ront of gain in forty-eight hour's determined. In the tosts uncler discussion the bricks were weighed at intervals up to many days immersion. 
THE TRANGTERSE TEST.

The writer considers the transverse test of paving brick to be one of the most valuable made, although he must confess that in this opinion he is not well supported by all other experimenter's on luving brick. As a result of his experience in making thousands of tests, the writer, nevertheless, believes that the transrerse test furnishes fully as reliable an index of the quality of

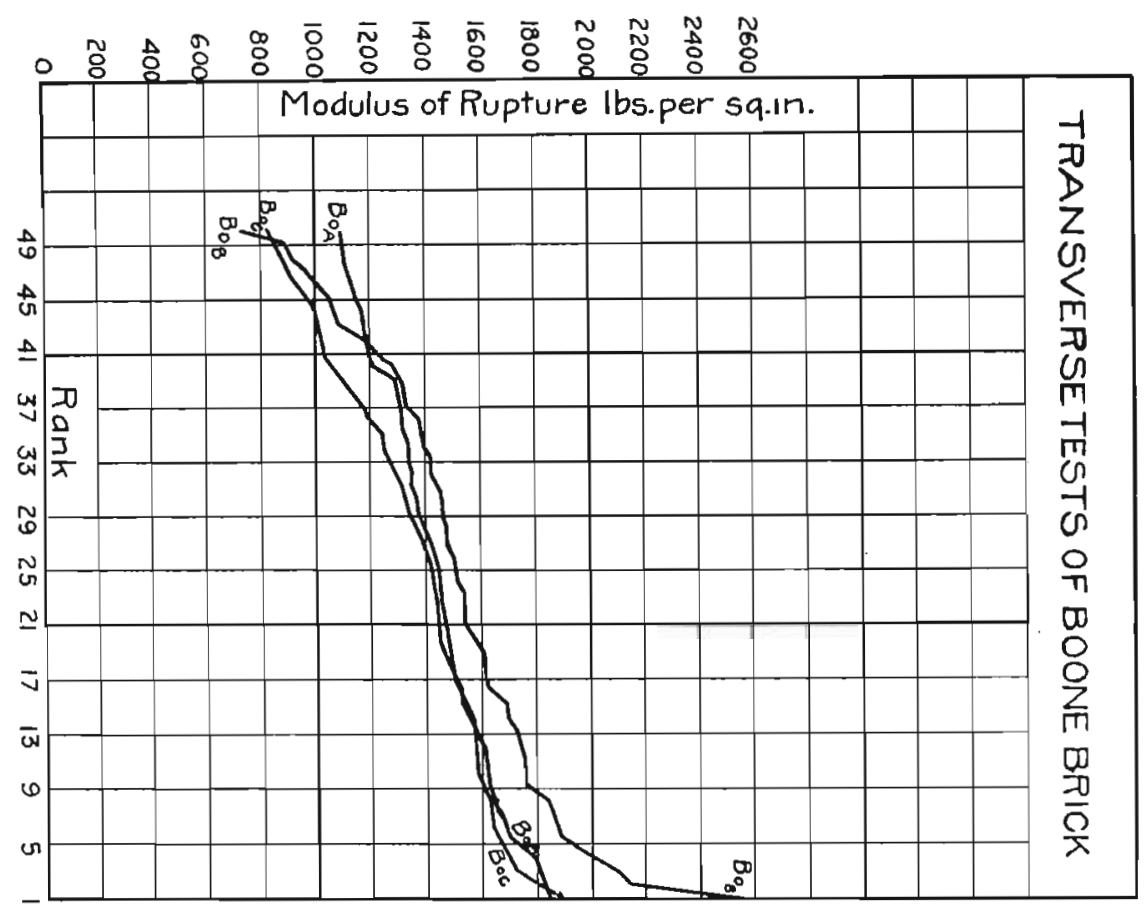

FIG. 121. Transverse tests of Bcone brick.

paving brick as any yet proposed. In fact, in some cases under his checrvation, where the guality of the brick was known in other ways than by test, the writer has leelieved that the transvorese test gave more accurate indications as to the relative quality of the brick than the rattler test. When we understand that actual use of brick in pavements has not always given results agreeing: with the rattler tests of the material, and when we 39 


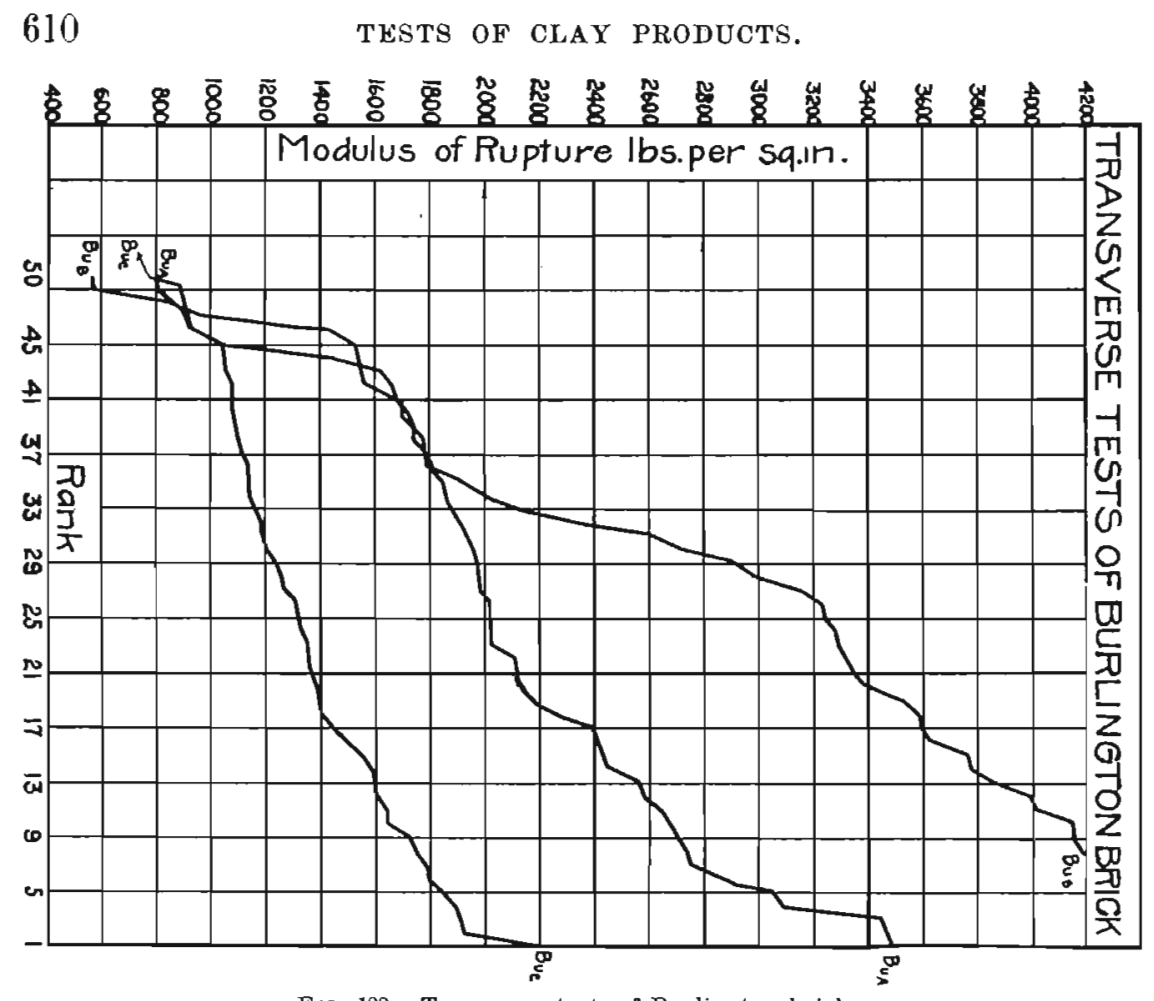

Fra. 122. Transverse tests of Burlington brick.

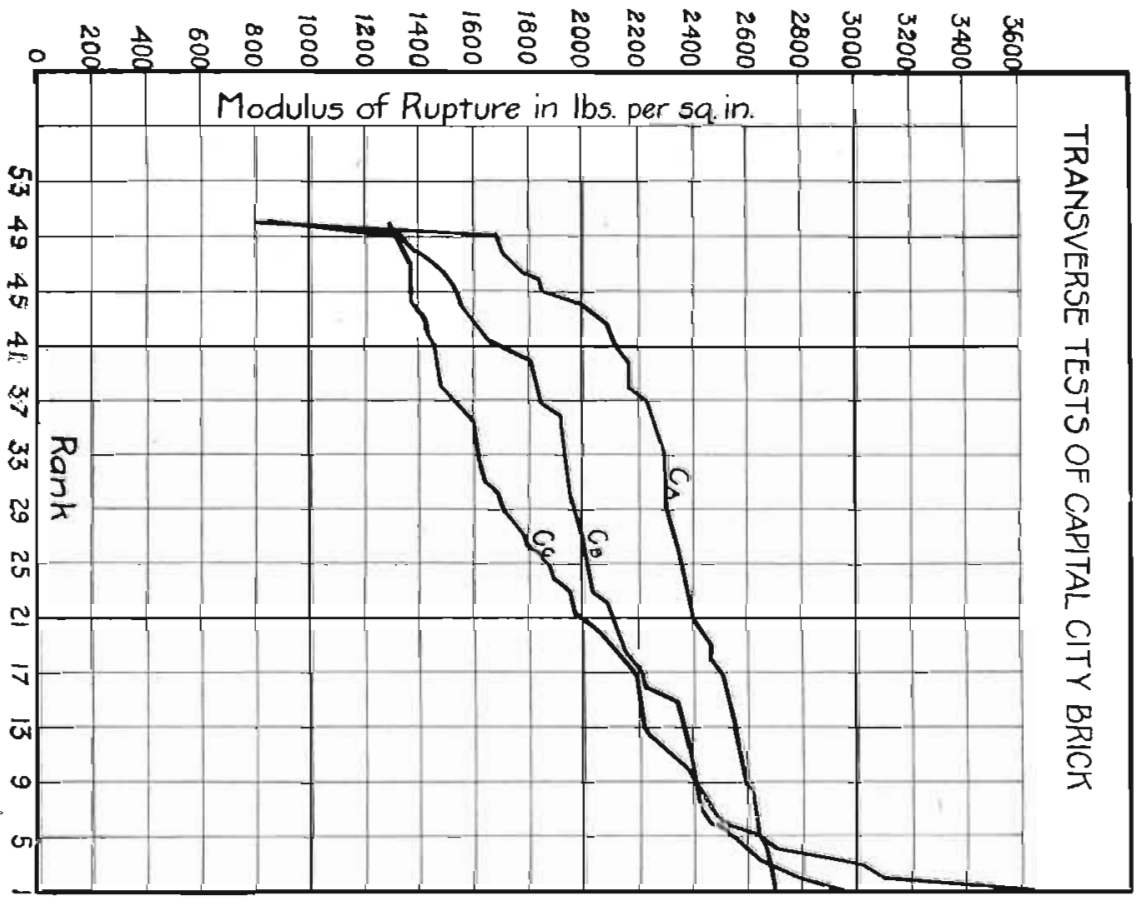

Fra. 123. Transverse tests of Capital City brick. 
PAVING BRICK TESTS.

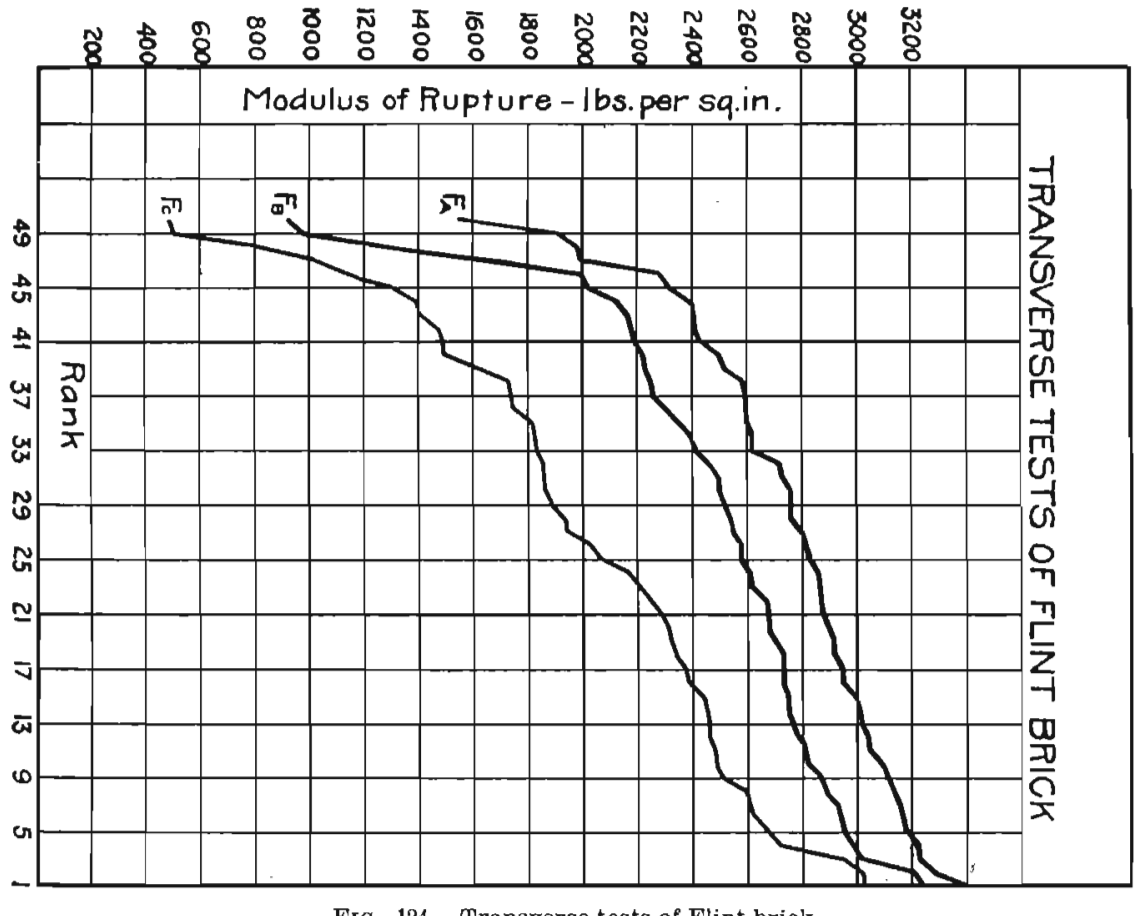

FIG. 124. Transverse tests of Flint brick.

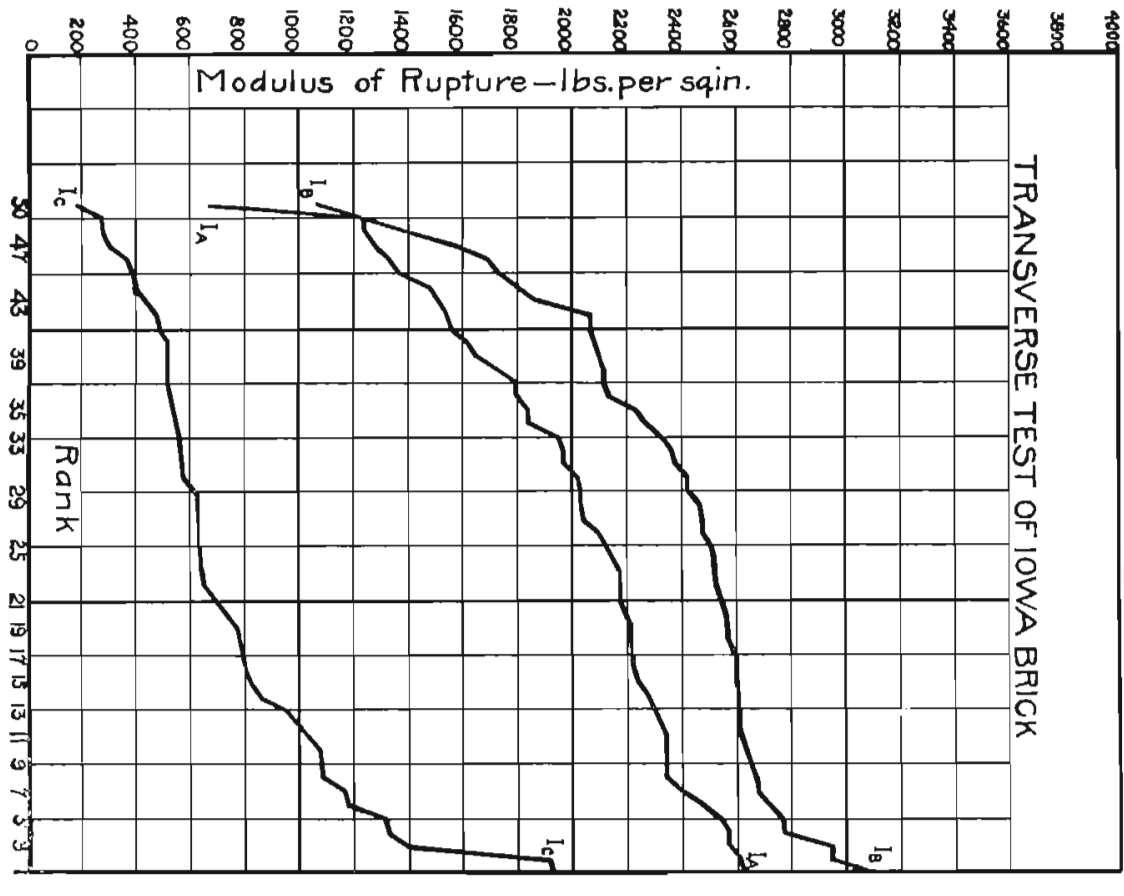

Fig. 125. Transverse tests of Iowa brick. 
further have been emibarrassed by the great diversity in the results of paving brick of apparently the same grade, we may well question the acceptance of the rattler tests as being infal-. lible and of itself' all-sufficient.

In the civil engineering laboratory at the Iowa State College the transverse test has been standardized in a somewhat different manner from that commonly followed by experimenters.

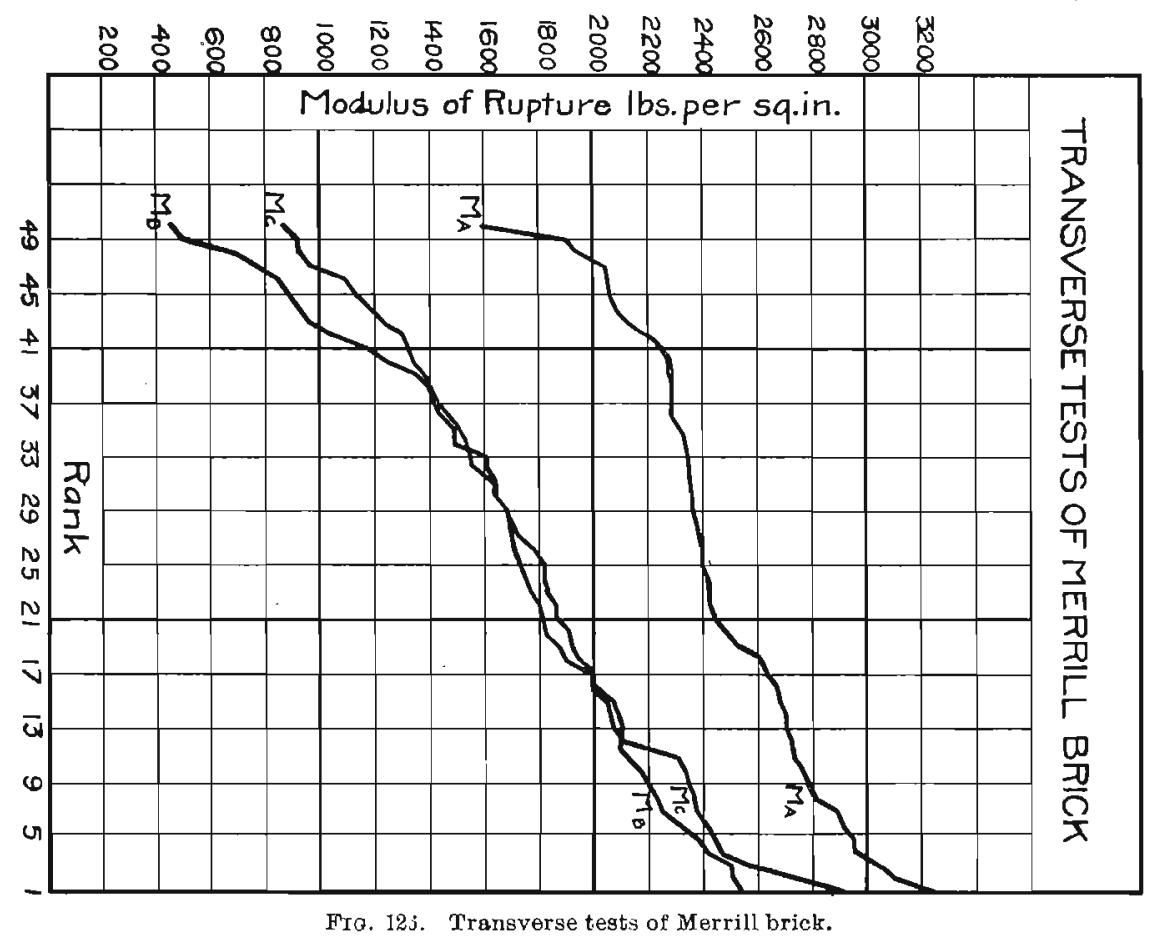

The brick are placed on edge, surppcrted near each end on knife edges six inches apart rounded both ways, and the load is applied at the center by an adjustable knife edge. Between all knife edges and the brick steel bearing blocks are placed to prevent knife edges cutting into the brick.

One great advantuge of the transverse test is that it fully exroses the interior structure of each brick tested and that it searches out any, hidden flaws. 
THE RATTLER TEST

The rattler test of paving brick is a test nct usually made of other materials of construction, but is a test which has been developed especially for this work. It has come to be considered universally the most reliable test of paving brick. In the street under actual conditions of wear brick fail mainly by abrasion from the blows of the horses' feet and the wheels of loaded vehicles. In the rattler test the brick pound against each otlier

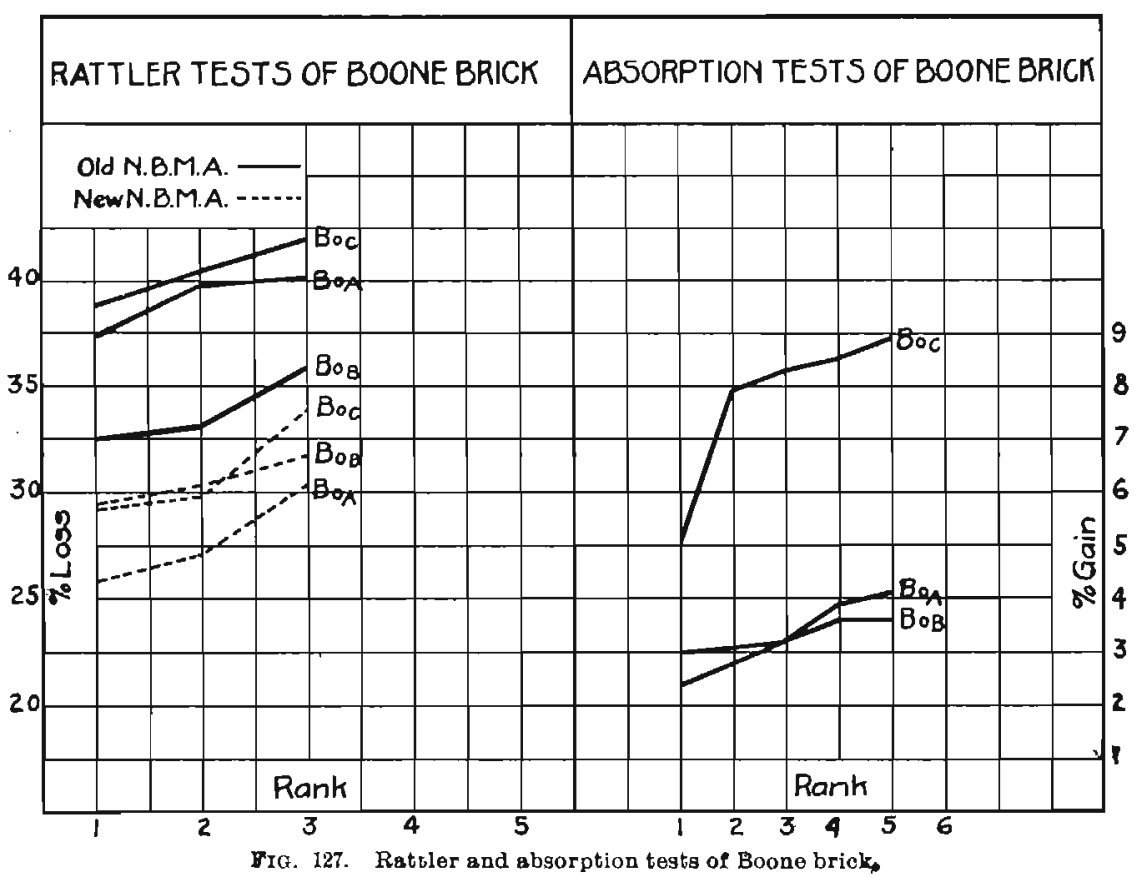

and against the sides of the rattler, and the iron in the charge alsc pounds the brick in a way to produce excessive wear mainly by abrasion, and the brick fail in a manner somewhat the same as in actual use in the street.

A great deal of attention has been given to the standardizing: of the rattler tests by the National Brick Manufacturers' Association, the work being done mainly by Professor Orton of the 
Ohio State University. As a result of this work the National Brick Manufacturers' Association first recommended a standard method of conducting the test with the rattler containing only brick, and that these should be placed in to the extent of 15 per cent of the volume.

Experience with this method of testing soon lead to abandoning it and to the adoption of another method, which Professor

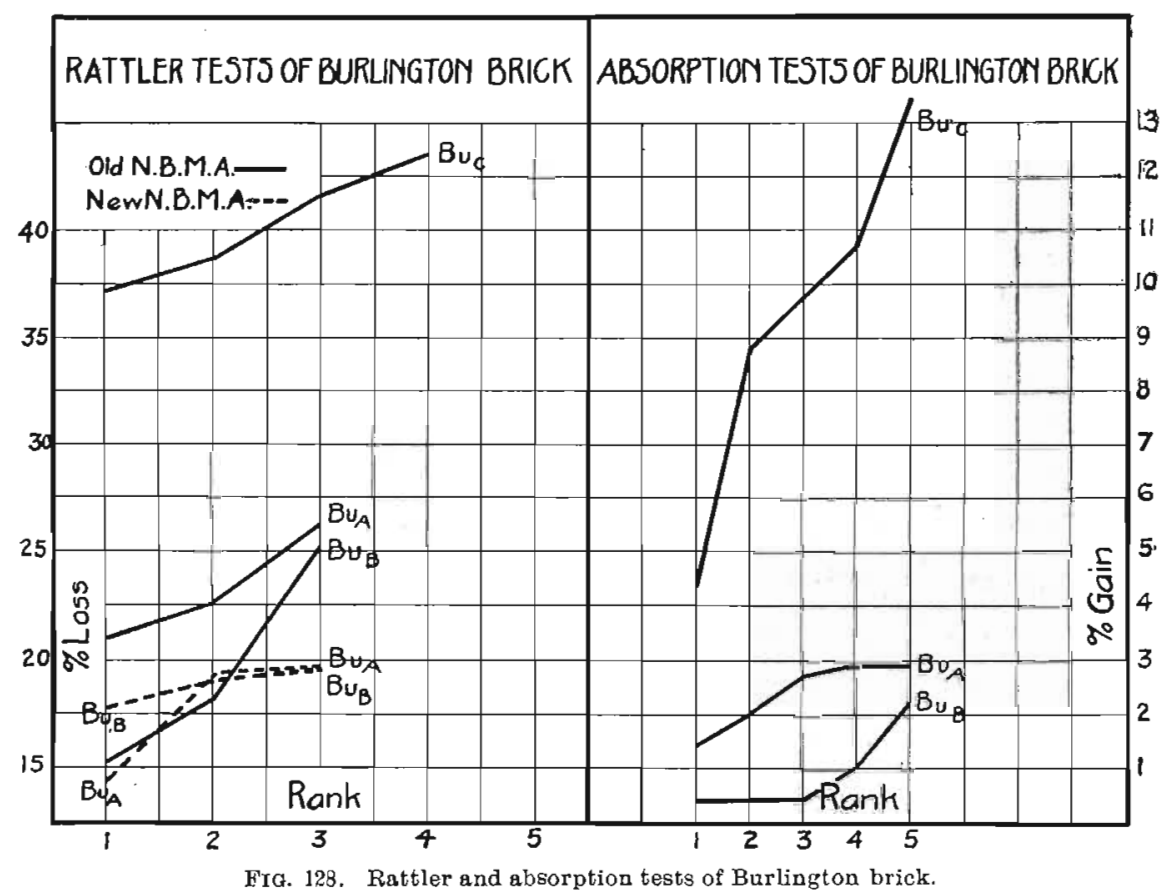

A. N. Talbot of the: University of Illinois took a prominent part in developing. In the diagrams given herewith the method first proposed by the N. B. M. A. is designated as the "old N. B. M. A. test" and the new method as the "new N. B. M. A. test." The change was made while this investigation was under way.

Still another method of conducting the rattler test has been proposed, in which the brick are clamped: around the interior perimeter of thel rattler so as to make a sort of cylindrical brick 

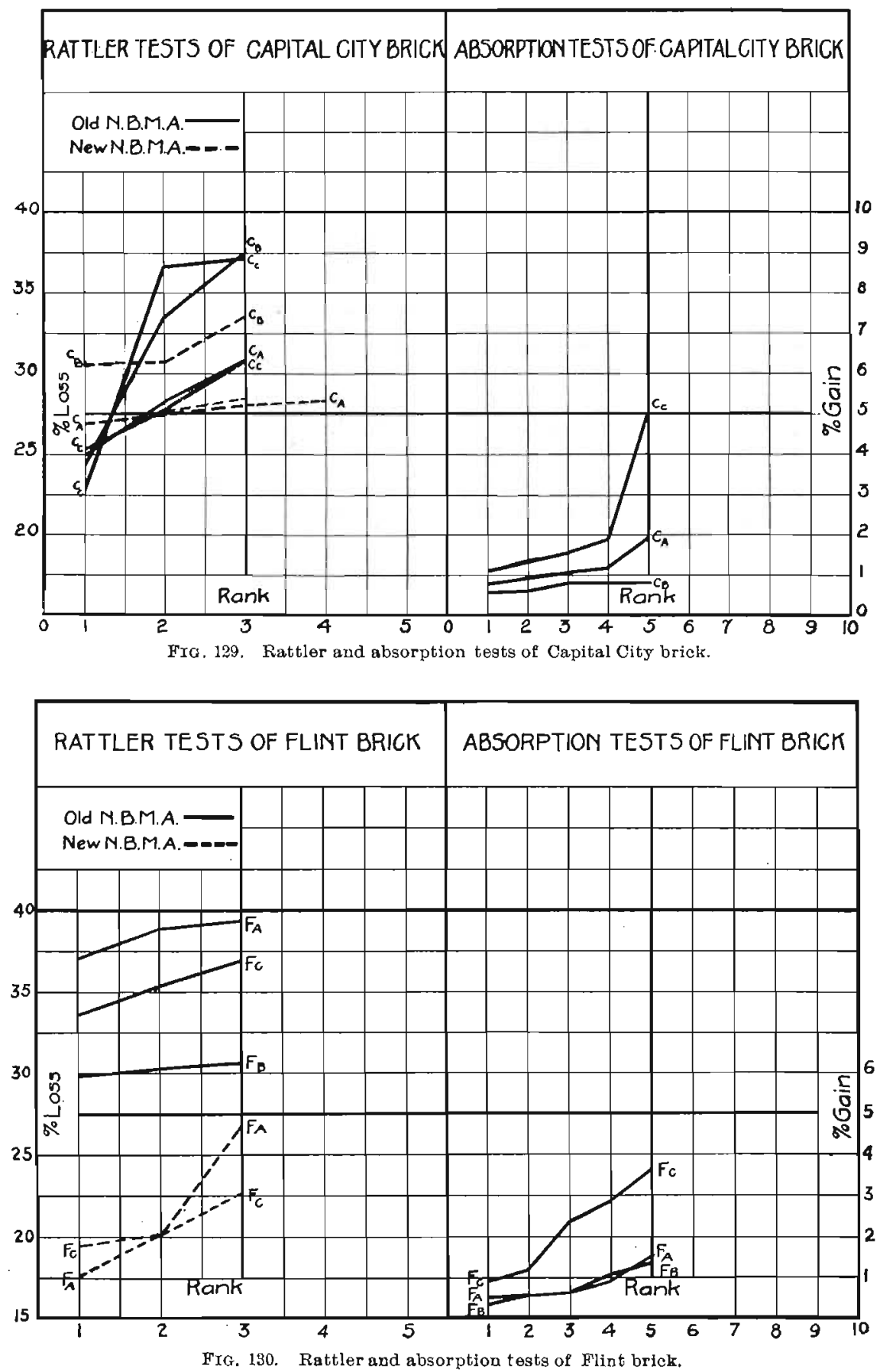
pavement. The charge of ircn in the machine then wears against only one edge of the brick in a way more closely resenbling the wear in the street. In 1901 a commission of engineel's consisting of the late Professor J. B. Johnson, dean of the college of engineering of the University of Wisconsin, Professor A. N. Talbot of the University of Illinois, Professor W. K. Hatt of Purdue University, and Professcr A. Marston of Towa

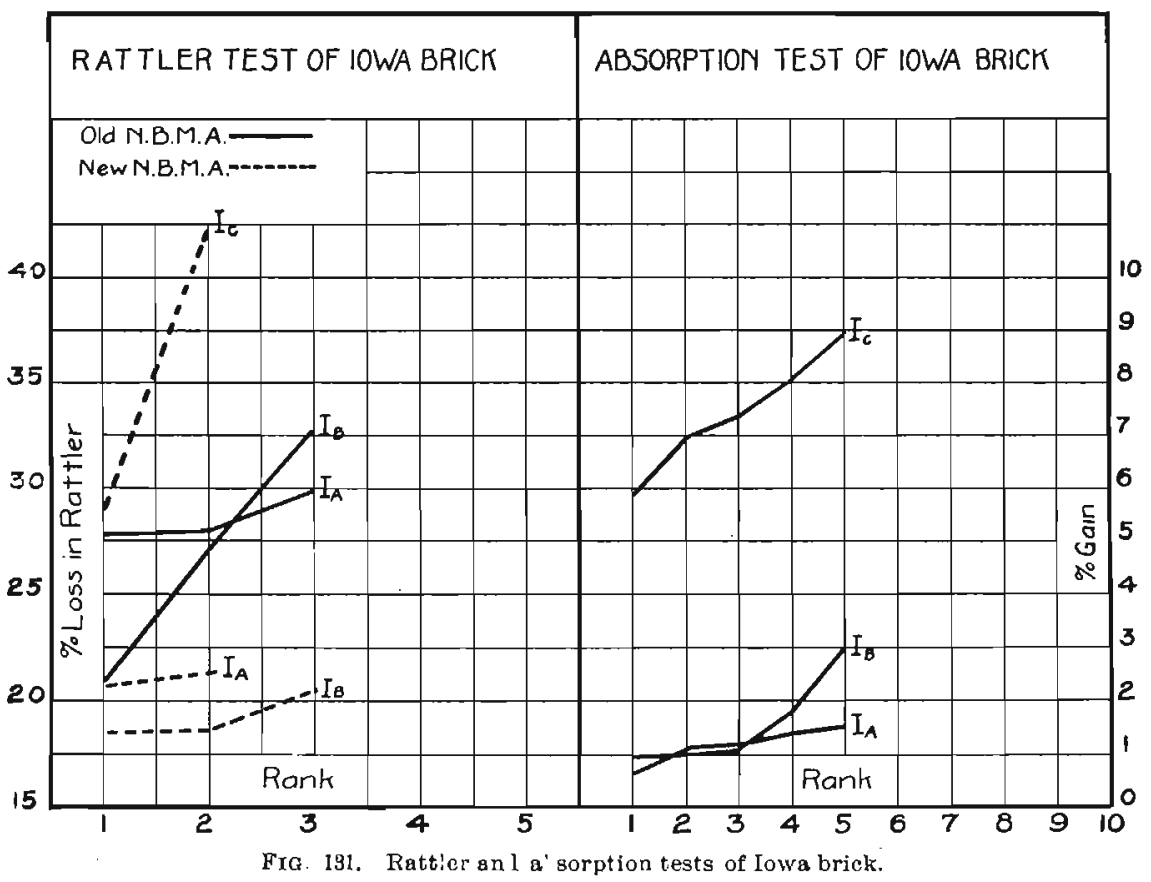

State College, met Professor Orton and a number of brick manrfacturers, and otlier people interested in paving brick tests at Columbus, Ohio, to report upon the advisability of adopting this oher method of testing. After careful consideration of the ex. tensive series of tests repcrted, this: commission advised against the adoption of the proposed method and recommended adherence to the old method, called in this paper the "new N. B. M. A. test." 
STANDARD METHOD OF CONDUCTING RATTLER TESTS. 617

It is very desirable that a standard method of conducting the rattler test should! be adopted universally and it is strongly recommended that all rattler tests should be conducted in accordance with the following specifications, which have been adopted as standard by the National Brick Manufacturers' Association:

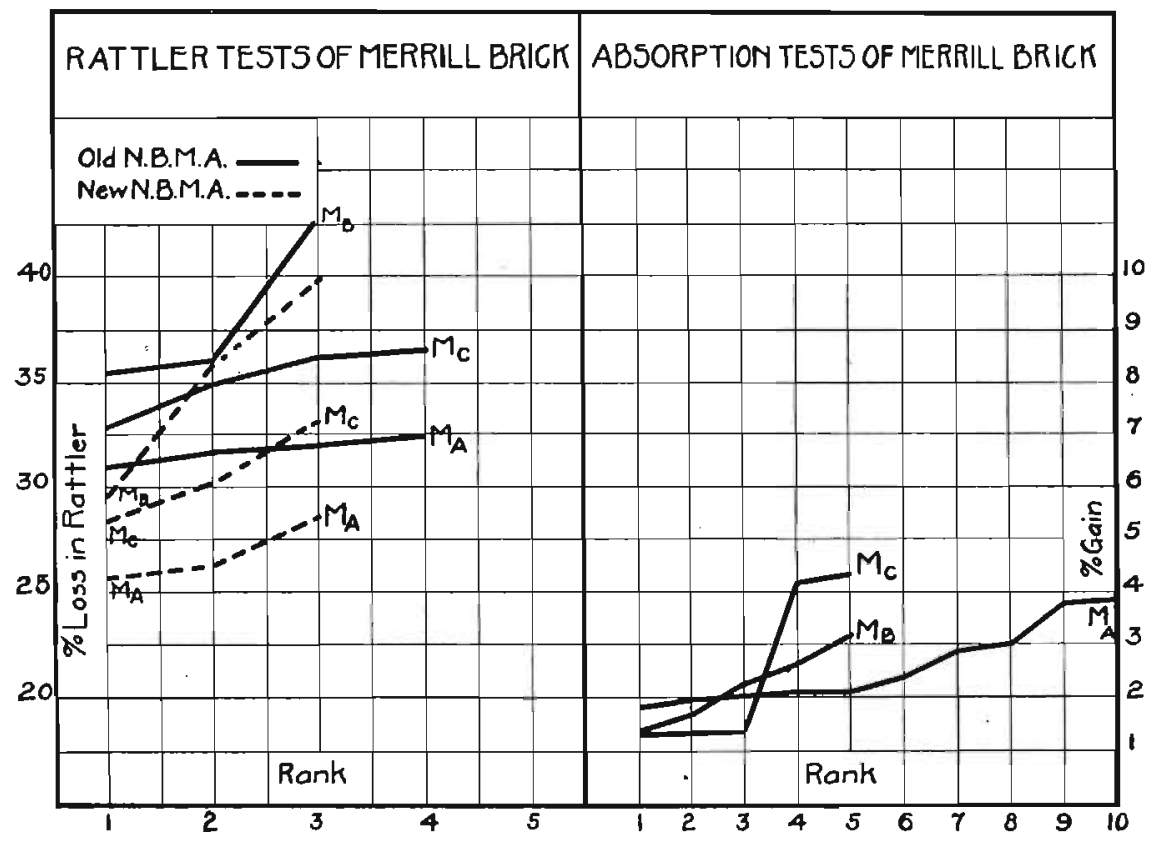

Fia. 182. Rattler and absorption tests of Merrill brick.

\section{SPECIFICATIONS FOR STANDARD METHOD OF CONDUCTING RATTLER TESTS.}

1. Dimensions of Machine.-The standard machine shall be 28 inches in diameter and 20 inches in length, measured inside the rattling chamber".

Other machines may be used, varying in diameter between 26 and 30 inches, and in length from 18 to 24 inches, but if this is dcne, a record must be attached to the official report. Long rattlers must be cut up into sections of suitable length by the insertion of an iron diaphragm at the proper point. 
2. Construction of the Machine.-The barrel may be driven by trunnions at one or both ends, or by rollers underneatl, but in no case shall a shaft pass though the rattler chamber. The cross-section of the barrel shall be a regular polygon, having fourteen sides. The heads shall be composed of gray cast-iron, not chilled nol" ase-harclened! The staves shall preferably be composed of steel plates, as cast-iron peaus and ultimately breaks under the wearing action on the inside. There shall be a space of cne-fourth of an inch between the staves for the escape of the dust and suall picces of waste.

Other machines may be used laving from twelve to: sixteen staves, with openings from cne-eighth to three-eighths of an inch between staves, but if this is done a record of it must be attached to the official report of the test.

3. Composition of the Charg's.-All tests must be executrd on charges containing but one make of paving material at a time. The charge shall be composed of the brick to be tested and iron abrasive material. The brick charge shall consist of that number of whole bricks or blocks, whose combined volume most

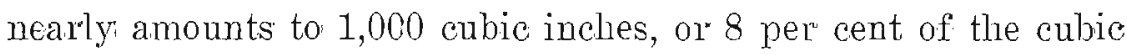
contents of the rattling chamber. (Nine, ten or eleven are the numbr required for the ordinary sizes on the market.) The abrasive charge shall consist of 300 pounds of shot made of ordimary machinery cast-iron. This sliot sluall be of two sizes, as described below and the shot charge shall be composed of onefourth (75 pounds) of the larger size and three-fourtis ( 225 pounds) of the smaller size.

4. Size of the Shot.-The larger size shall weigh about $7 / 2$ founds and be about $2 / 2$ inches square and $4 / 2$ inclies long, with slightly rounded edges. The smaller size shall be $1 / 2$-inch cubes, weigling about seven-eighths of a prind each, with square corners and edges. The individual shot shall be replaced by new ones when they have lost cne-tenth of their original weight. 
STANDARD METHOD OF CONDUCTING RATTLER TESTS. 619

5. Revolutions of the Charge.-The number of revolutions of the standard test shall be 1,800, and the speed of rotation shall not fall belcw: 28 nor exceed 30 per minute. The belt power shall be sufficient to rotate the rattler at the same speed, whether charged! or empty.

6. Condition of the Charge.--The bricks composing: the charge shall be thoroughly dried before making the test.

7. The Calculation of the Results. - The loss shall be calculated in percentages of the weiglit of the dry brick composing the charge, and no result shall be considered as official unless it is the average of two distinct and complete tests, made on separate charges of brick.

While the rattler tests of Iowa paxing brick are alearly shown by the diagrans given in this article, yet.for the purpose of wreparing specifications it is desirable that the numerical values should he available. These are presented in the following table.

In this table some rattler tests of the Purington paving brick, manufactured at Galesburg, Illinois, are also given for the purpose of comparison, because these Purington brick are so extensively used for pavements. Unfortunately we are unable to say that the Iowa brick make a better showing than the Purington brick, but it may be stated without fear of contra. diction that the best grades of Iowa paring brick; as manufactured in encrmous quantities at Des Moines during many years prast, have demonstrated their good quality and reliability when used in brick pavements. 
RATTLER TESTS OF IOWA PAVING BRICK.

PER CENT. OS LOSSES IN WEIGHT.

\begin{tabular}{|c|c|c|c|c|c|c|}
\hline \multirow[b]{3}{*}{ KIND OF BRICK. } & \multicolumn{6}{|c|}{ GRADE OF BRICK. } \\
\hline & \multicolumn{2}{|c|}{ No. 1.} & \multicolumn{2}{|c|}{ Overburned. } & \multicolumn{2}{|c|}{$\begin{array}{l}\text { Under- } \\
\text { burned. }\end{array}$} \\
\hline & 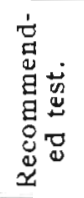 & 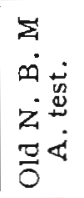 & 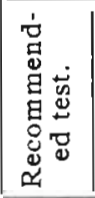 & 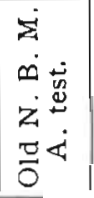 & 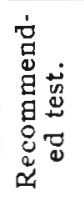 & 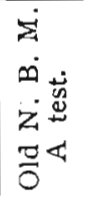 \\
\hline Flint, Des Moines........... & $\begin{array}{c}17.6 \\
201 \\
\geq 6.8 \\
\ldots\end{array}$ & $\begin{array}{c}39.1 \\
37.0 \\
38.9 \\
\ldots \ldots\end{array}$ & $\begin{array}{ll}37 & 0 \\
33 & .2 \\
29 & 8 \\
30 & 3\end{array}$ & $\begin{array}{c}30.6 \\
38.1 \\
31.9 \\
\ldots \ldots\end{array}$ & $\begin{array}{c}22.7 \\
20.1 \\
19.5 \\
\ldots . .\end{array}$ & $\begin{array}{r}33.5 \\
35.3 \\
36.9 \\
\therefore \ldots .\end{array}$ \\
\hline Average $\ldots \ldots \ldots \ldots \ldots \ldots \ldots \ldots$ & 215 & 38.3 & 32.5 & 33.3 & 20.8 & 35.2 \\
\hline Iowa, Des Moines............. & $\begin{array}{l}27.5 \\
21.3 \\
20.7\end{array}$ & $\begin{array}{l}27.9 \\
29.8 \\
28.0\end{array}$ & $\begin{array}{l}18.5 \\
18.7 \\
20.5\end{array}$ & $\begin{array}{l}32.8 \\
27.1 \\
20.9\end{array}$ & $\begin{array}{r}28.8 \\
42.1 \\
\cdots\end{array}$ & $\begin{array}{r}36.9 \\
\cdots \cdots \\
\cdots \cdots\end{array}$ \\
\hline Average............. & 23.1 & 28.5 & :9.2 & 26.9 & 35.5 & 36.9 \\
\hline Capital City, Des Moines....... & $\begin{array}{l}26.9 \\
28.3 \\
28.1 \\
\ldots .\end{array}$ & $\begin{array}{r}28.3 \\
30.8 \\
24.9 \\
\ldots .\end{array}$ & $\begin{array}{c}30.7 \\
33.5 \\
30.5 \\
\ldots \ldots .\end{array}$ & $\begin{array}{l}37.5 \\
20.9 \\
24.3 \\
33.5\end{array}$ & $\begin{array}{c}27.8 \\
25.2 \\
30.9 \\
\ldots \ldots\end{array}$ & $\begin{array}{r}37.2 \\
36.6 \\
22.7 \\
\ldots \ldots\end{array}$ \\
\hline Average..$\ldots \ldots \ldots \ldots \ldots \ldots \ldots \ldots$ & 277 & 28.0 & 31.6 & $: 9.0$ & 27.9 & 32.2 \\
\hline Merrill, Des Moines... & $\begin{array}{l}28.5 \\
256 \\
26.2 \\
\ldots .\end{array}$ & $\begin{array}{l}32.3 \\
31.7 \\
31.0 \\
32.0\end{array}$ & $\begin{array}{c}36.5 \\
33.9 \\
39.3 \\
\ldots \ldots\end{array}$ & 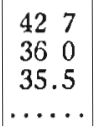 & $\begin{array}{c}33.2 \\
30.1 \\
284 \\
\ldots \ldots\end{array}$ & $\begin{array}{l}32.9 \\
34.9 \\
36.2 \\
36.5\end{array}$ \\
\hline Average $\ldots \ldots \ldots \ldots \ldots \ldots \ldots \ldots \ldots$ & 267 & 32.3 & 366 & 38.0 & 30.6 & 35.1 \\
\hline Burlington... & $\begin{array}{c}19.7 \\
14.4 \\
19.3 \\
\ldots \ldots\end{array}$ & $\begin{array}{l}26.3 \\
21.0 \\
27.6 \\
\ldots .\end{array}$ & $\begin{array}{c}17.6 \\
19.3 \\
29.1 \\
\ldots \ldots\end{array}$ & $\begin{array}{l}18.1 \\
25.3 \\
15.3 \\
\ldots \ldots \ldots\end{array}$ & $\begin{array}{c}34.7 \\
\ldots \ldots \\
\ldots \ldots \\
\ldots \ldots\end{array}$ & $\begin{array}{l}37.2 \\
38.8 \\
43.6 \\
41.7\end{array}$ \\
\hline Average $\ldots \ldots \ldots \ldots \ldots \ldots \ldots$ & 17.8 & 25.0 & 18.6 & 19.6 & 34.7 & 40.3 \\
\hline Boone.... & $\begin{array}{l}30.3 \\
28.8 \\
27.2\end{array}$ & $\begin{array}{l}39.8 \\
37.4 \\
74.2\end{array}$ & $\begin{array}{l}31.7 \\
30.3 \\
29.5\end{array}$ & $\begin{array}{l}359 \\
32.5 \\
33.1\end{array}$ & $\begin{array}{l}29.8 \\
29.2 \\
33.6\end{array}$ & $\begin{array}{l}40.4 \\
38.7 \\
41.9\end{array}$ \\
\hline Average............... & 28.7 & 39.1 & 30.5 & 33.8 & 30.9 & 40.3 \\
\hline $\begin{array}{l}\text { Purington Paving Brick, } \\
\text { Galesburg, lllinois........ }\end{array}$ & $\begin{array}{c}\ldots \ldots \\
\ldots \ldots \\
\ldots \ldots \\
\ldots\end{array}$ & $\begin{array}{l}17.8 \\
18.9 \\
19.0 \\
20.3\end{array}$ & $\begin{array}{c}\cdots \cdots \\
\cdots \\
\cdots \\
\cdots \\
\cdots\end{array}$ & $\begin{array}{c}19.0 \\
20.1 \\
22.0 \\
\ldots \ldots\end{array}$ & $\begin{array}{l}\ldots \ldots \\
\ldots \ldots \\
\ldots \ldots \\
\ldots \ldots\end{array}$ & $\begin{array}{r}16.3 \\
22.8 \\
30.6 \\
\ldots \ldots\end{array}$ \\
\hline Average............. & & 190 & & 20.4 & & 23.2 \\
\hline
\end{tabular}

